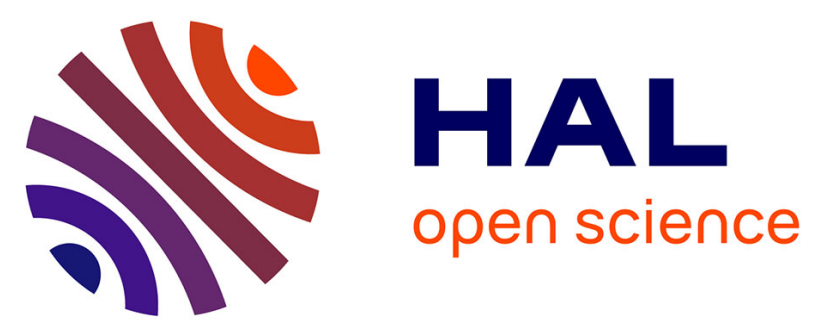

\title{
Surface water temperature changes in the high latitudes of the southern hemisphere over the Last Glacial-Interglacial Cycle
}

Jean-Jacques Pichon, Laurent D Labeyrie, Gilles Bareille, Monique

Labracherie, Josette Duprat, Jean Jouzel

\section{To cite this version:}

Jean-Jacques Pichon, Laurent D Labeyrie, Gilles Bareille, Monique Labracherie, Josette Duprat, et al.. Surface water temperature changes in the high latitudes of the southern hemisphere over the Last Glacial-Interglacial Cycle. Paleoceanography, 1992, 7 (3), pp.289-318. 10.1029/92PA00709 . hal-03334776

\section{HAL Id: hal-03334776 \\ https://hal.science/hal-03334776}

Submitted on 5 Sep 2021

HAL is a multi-disciplinary open access archive for the deposit and dissemination of scientific research documents, whether they are published or not. The documents may come from teaching and research institutions in France or abroad, or from public or private research centers.
L'archive ouverte pluridisciplinaire HAL, est destinée au dépôt et à la diffusion de documents scientifiques de niveau recherche, publiés ou non, émanant des établissements d'enseignement et de recherche français ou étrangers, des laboratoires publics ou privés. 


\section{SURFACE WATER TEMPERATURE CHANGES IN THE HIGH LATITUDES OF THE SOUTHERN HEMISPHERE OVER THE LAST GLACIAL- INTERGLACIAL CYCLE}

Jean-Jacques Pichon, ${ }^{1}$ Laurent D. Labeyrie, ${ }^{2}$ Gilles Bareille, ${ }^{1}$ Monique Labracherie, 1 Josette Duprat, 1 and Jean Jouzel 3,4

\footnotetext{
1Département de Géologie et Océanographie, CNRS URA.197, Université de Bordeaux 1, Talence, France.

${ }^{2}$ Centre des Faibles Radioactivités, Laboratoire mixte CNRS-CEA, Gif-sur-Yvette, France.

${ }^{3}$ Laboratoire de Modélisation du Climat et de l'Environnement, Gif sur Yvette, France

${ }^{4}$ Also at Laboratoire de Glaciologie et de Geophysique de l'Environnement, St Martin d'Hères, France.
}

\author{
Copyright 1992 \\ by the American Geophysical Union. \\ Paper number 92PA00709. \\ 0883-8305/92/92PA-00709\$10.00
}

gives accurate estimates of SST over a wide range of biosiliceous dissolution. A transfer function (DTF $166 / 34 / 4$ ) is derived from the distribution of these factors versus summer SST. Its standard error is \pm $1^{\circ} \mathrm{C}$ in the -1 to $+10^{\circ} \mathrm{C}$ summer temperature range. This transfer function is used to estimate SST changes in two southern ocean cores $\left(43^{\circ} \mathrm{S}\right.$ and $\left.55^{\circ} \mathrm{S}\right)$ which cover the last climatic cycle. The time scale is derived from the changes in foraminiferal oxygen and carbon isotopic ratios. The reconstructed SST records present strong analogies with the air temperature record over Antarctica at the Vostok site, derived from changes in the isotopic ratio of the ice. This similarity may be used to compare the oceanic isotope stratigraphy and the Vostok time scale derived from ice flow model. The oceanic time scale, if taken at face value, would indicate that large changes in ice accumulation rates occurred between warm and cold periods.

\section{INTRODUCTION}

Paleoclimatological studies in the southern hemisphere high latitudes are important for understanding some of the major phenomena controlling climatic changes over the last $10^{3}$ to $10^{5}$ years. The interactions between surface ocean, ice, and atmosphere should be easier to model in the southern than in the northern hemisphere, because of the near axial geometry of the Antarctic continent and the surrounding southern ocean, permanent ice cover over Antarctica and the relative stability of the Antarctic Polar Front (APF) during glacialinterglacial transitions [Hays et al., 1976a]. The Vostok ice core, which covers the last clinatic cycle 
[Lorius et al., 1985], provides a high-resolution deuterium and oxygen isotopic record interpretable in terms of temperature changes over Antarctica [Jouzel et al., 1987]. The atmospheric $\mathrm{CO}_{2}$ content during that period has been measured in the air trapped during ice formation [Barnola et al., 1987]. Age models for the Vostok core and its included gas, derived from estimated ice accumulation and flow rates [Lorius et al., 1985] differ significantly from the time scale developed for the ocean sediments, with a longer apparent duration for the last interglacial. This is a major problem for the study of climatic feedbacks between changes in insolation, ocean circulation, and $\mathrm{pCO}_{2}$ in the atmosphere [Lorius et al., 1990; Sowers et al., 1991]. Petit et al. [1990] proposed to use the close similarity that exists between the changes in atmospheric dust content of the Vostok core and available dust records covering the last 150 ka [Kukla, 1987; Robinson, 1986; Kent, 1982] to construct a common chronostratigraphy between the ice and ocean sediment records. However, there are no indications that the different dust records are synchronous. Another approach may be to use the close climatological connections between the Antarctic ice sheet and the surrounding southern ocean. The sea surface temperature (SST) changes at high latitudes influence the temperature over Antarctica by transfer of heat and atmospheric water. Lorius et al. [1990] have shown the good covariance existing between the reconstructed changes in air temperature at Vostok and the SST record derived from a radiolarian transfer function in sediment core RC11-120 [Hays et al., 1976b, Martinson et al., 1987]. Limitations in the interpretation of this relationship derive from the location of this sediment core north of the Antarctic Polar Front and thus still under the strong influence of the subtropical/transitional waters. Time lags have been observed between southern ocean temperature records and the global climatic signal [Hays, 1978; Morley and Robinson, 1980; CLIMAP Project Members, 1984; Labracherie et al., 1989], as well as between isotopic records of planktonic and benthic foraminifera [Labeyrie et al. 1986].
We present here a reconstruction of SST changes over the last $140 \mathrm{kyr}$ in two cores from the subpolar (MD 84 527) and polar (MD 84 551) waters in the southern ocean using a transfer function based upon floral assemblages derived from that developed by Pichon et al. [1987], with an increased core top reference data base and a correction of the effect of dissolution as described in Pichon et al [1992]. The time frame is derived from the changes in foraminiferal isotopic ratio, and the results are compared with the changes in air temperature over the ice estimated at Vostok [Lorius et al 1985].

\section{DIATOM TRANSFER FUNCTION}

\section{Materials and Methods}

Pichon et al. [1987] have shown that the geographic distribution of Antarctic flora (diatoms and silicoflagellates) in modern core top samples from the southern ocean coincides with present-day sea surface parameters (summer SST, phosphate concentration, and annual sea ice cover). The quantitative method used here to derive the transfer function follows Imbrie and Kipp [1971]. The aim of the present study is to increase the range of applicability of the diatom transfer function (DTF) and its accuracy, particularly in view of the bias possibly introduced by differential dissolution of the fossil diatom assemblages. The geographic sample coverage was increased from 28 to 124 core top samples, thus permiting construction of more detailed descriptions of regional biogeography patterns and temperature gradients (from $+14^{\circ} \mathrm{C}$ to $1.9^{\circ} \mathrm{C}$ ). The 124 samples from the southern ocean consist of 77 samples from box cores, 40 samples from high-sedimentation-rate piston cores, and seven samples from trigger-weight cores collected between $67^{\circ} \mathrm{W}$ and $140^{\circ} \mathrm{E}$ and $37^{\circ} \mathrm{S}$ and $78^{\circ} \mathrm{S}$ (Table 1 and Figure 1). In all cores, the sediment-water interface was retrieved with no apparent disturbance and, based on micropaleontological, sedimentological and statistical arguments [Pichon et al., 1987], represents

TABLE 1. Positions and Water Depths of Surface Samples Used in This Study

\begin{tabular}{|c|c|c|c|c|c|c|c|}
\hline Core & Latitude (S) & Longitude & Depth, m & Core & Latitude ( $S$ & Longitude & Depth, m \\
\hline MD24-KK02 & $54^{\circ} 13,0^{\prime}$ & $03^{\circ} 31,0^{\prime} \mathrm{E}$ & 1522 & KR88-30 & $61^{\circ} 00,2^{\prime}$ & $93^{\circ} 11,9^{\prime} \mathrm{E}$ & 4300 \\
\hline MD24-KK32 & $54^{\circ} 30,0^{\prime}$ & $03^{\circ} 48,4^{\prime} \mathrm{E}$ & 2020 & KR88-31 & & $89^{\circ} 24,3^{\prime} \mathrm{E}$ & 4595 \\
\hline MD24-KK35 & $53^{\circ}$ & & 2725 & & & $24^{\circ}$ & 7906 \\
\hline MD24-K & & & 29 & V14 & & W & 3546 \\
\hline $\mathrm{MD}$ & & & & V16 & & & 4575 \\
\hline MD7? & $44^{\circ}$ & $53^{\circ}$ & 3429 & & & & 16 \\
\hline & & & & & & & \\
\hline $\mathrm{MD}$ & & $00^{\circ} 4$ & 1940 & $\mathrm{RC} 1$ & $49^{\circ} 08,0^{\prime}$ & W & 5537 \\
\hline & & & $38 \mathrm{C}$ & & $53^{\circ} 03,0^{\prime}$ & $16^{\circ} 27,0^{\prime} \mathrm{W}$ & 4098 \\
\hline MD8 & & $16^{\circ} 39,0^{\prime} \mathrm{W}$ & 3640 & RC11-78 & $50^{\circ} 52,0^{\prime}$ & $09^{\circ} 52,0^{\prime} \mathrm{W}$ & 3115 \\
\hline
\end{tabular}


TABLE 1. (continued)

\begin{tabular}{|c|c|c|c|c|c|c|c|}
\hline Core & Latitude (S & Longitude & Depth, $n$ & n Core & Latitude ( & 5) Longitude & Depth, m \\
\hline MD82-436 & $61^{\circ} 13,6^{\prime}$ & $19^{\circ} 28,8^{\prime} \mathrm{W}$ & 3620 & RC11-80 & $46^{\circ} 45,0^{\prime}$ & $00^{\circ} 03,0^{\prime} \mathrm{W}$ & 3656 \\
\hline MD84-529 & $48^{\circ} 54,3^{\prime}$ & $61^{\circ} 59,8^{\prime} \mathrm{E}$ & 2600 & RC11-90 & $56^{\circ} 38,0^{\prime}$ & $25^{\circ} 43,0^{\prime} \mathrm{E}$ & 5334 \\
\hline MD84-530 & $66^{\circ} 06,6^{\prime}$ & $73^{\circ} 59,1^{\prime} \mathrm{E}$ & 2412 & RC11-118 & & $71^{\circ} 32,0^{\prime} \mathrm{E}$ & 4354 \\
\hline MD84-531 & $66^{\circ} 57,7^{\prime}$ & $75^{\circ} 24,6^{\prime} \mathrm{E}$ & 365 & RC11-119 & $40^{\circ} 18,0^{\prime}$ & $74^{\circ} 34,0^{\prime} \mathrm{E}$ & 3709 \\
\hline MD84-532 & $66^{\circ} 06,9^{\prime}$ & $76^{\circ} 45,6^{\prime} \mathrm{E}$ & 2700 & RC12-292 & $39^{\circ} 40,6^{\prime}$ & $15^{\circ} 28,5^{\prime} \mathrm{W}$ & 3541 \\
\hline MD84-533 & $65^{\circ} 09,1^{\prime}$ & $78^{\circ} 21,2^{\prime} \mathrm{E}$ & 3363 & RC13-255 & $50^{\circ} 34,0^{\prime}$ & $02^{\circ} 53,7^{\prime} \mathrm{E}$ & 3332 \\
\hline ID84-540 & $60^{\circ} 44,5^{\prime}$ & $86^{\circ} 23,3^{\prime} \mathrm{E}$ & 3964 & RC13-257 & $55^{\circ} 02,2^{\prime}$ & $03^{\circ} 00,1^{\prime} \mathrm{W}$ & 2837 \\
\hline ID84-552 & $54^{\circ} 55,4^{\prime}$ & $73^{\circ} 50,0^{\prime} \mathrm{E}$ & 1780 & $\mathrm{RC} 13-263$ & $53^{\circ} 48,3^{\prime}$ & $08^{\circ} 13,0^{\prime} \mathrm{W}$ & 3389 \\
\hline MD84-557 & $53^{\circ} 19,6^{\prime}$ & $75^{\circ} 48,0^{\prime} \mathrm{E}$ & 1080 & RC13-268 & $57^{\circ} 02,3^{\prime}$ & $00^{\circ} 05,6^{\prime} \mathrm{W}$ & 4005 \\
\hline $1 D 84-561$ & $53^{\circ} 05,3^{\prime}$ & $71^{\circ} 36,4^{\prime} \mathrm{E}$ & 1754 & RC13-269 & $52^{\circ} 37,6^{\prime}$ & $00^{\circ} 07,5^{\prime} \mathrm{E}$ & 2591 \\
\hline $1 D 84-562$ & $51^{\circ} 55,1^{\prime}$ & $68^{\circ} 13,6^{\prime} \mathrm{E}$ & 3553 & RC13-270 & $55^{\circ} 28,8^{\prime}$ & $04^{\circ} 38,2^{\prime} \mathrm{E}$ & 3160 \\
\hline D84-563 & $50^{\circ} 42,7^{\prime}$ & $68^{\circ} 09,1^{\prime} \mathrm{E}$ & 1720 & RC13-272 & $55^{\circ} 05,1^{\prime}$ & $08^{\circ} 00,0^{\prime} \mathrm{E}$ & 2538 \\
\hline $1084-569$ & $47^{\circ} 38,6^{\prime}$ & $73^{\circ} 23,1^{\prime} \mathrm{E}$ & 2385 & $\mathrm{RC} 13-273$ & $55^{\circ} 04,5^{\prime}$ & $11^{\circ} 34,5^{\prime} \mathrm{E}$ & 4967 \\
\hline R87-01 & $52^{\circ} 32,2^{\prime}$ & $31^{\circ} 11,0^{\prime} \mathrm{W}$ & 3510 & RC13-274 & $53^{\circ} 09,0^{\prime}$ & $12^{\circ} 25,6^{\prime} \mathrm{E}$ & 3372 \\
\hline R87-02 & $56^{\circ} 27,6^{\prime}$ & $33^{\circ} 58,5^{\prime} \mathrm{W}$ & 3350 & RC15-91 & $49^{\circ} 55,3^{\prime}$ & $15^{\circ} 34,1^{\prime} \mathrm{W}$ & 3775 \\
\hline R87-03 & $60^{\circ} 13,3^{\prime}$ & $48^{\circ} 56,9^{\prime} \mathrm{W}$ & 1300 & RC17-56 & $65^{\circ} 24,0^{\prime}$ & $37^{\circ} 43,0^{\prime} \mathrm{E}$ & 4794 \\
\hline R87-05 & $64^{\circ} 03,3^{\prime}$ & $7,2^{\prime} \mathrm{W}$ & 2810 & IO1176-55 & $53^{\circ} 22,9^{\prime}$ & $06^{\circ} 39,6^{\prime} \mathrm{E}$ & 2926 \\
\hline R87-06 & $63^{\circ} 03,6^{\prime}$ & $63^{\circ} 03,7^{\prime} \mathrm{W}$ & 630 & IO1176-65 & $57^{\circ} 12,5^{\prime}$ & $08^{\circ} 12,4^{\prime} \mathrm{E}$ & 5483 \\
\hline R87-07 & $62^{\circ} 21,2^{\prime}$ & $57^{\circ} 58,3^{\prime} \mathrm{W}$ & 2810 & IO1 176-82 & $49^{\circ} 31,2^{\prime}$ & $13^{\circ} 11,5^{\prime} \mathrm{E}$ & 4100 \\
\hline R87-08 & $60^{\circ} 55,2^{\prime}$ & $56^{\circ} 26,3^{\prime} \mathrm{W}$ & 2150 & $101176-86$ & $48^{\circ} 02,3^{\prime}$ & $13^{\circ} 49,0^{\prime} \mathrm{E}$ & 4338 \\
\hline $87-10$ & $59^{\circ} 39,6^{\prime}$ & $51^{\circ} 16,6^{\prime} \mathrm{W}$ & 2820 & IO1176-88 & $46^{\circ} 57,8^{\prime}$ & $14^{\circ} 18,2^{\prime} \mathrm{E}$ & 5106 \\
\hline KR87-12 & $54^{\circ} 55,8^{\prime}$ & $39^{\circ} 47,6^{\prime} \mathrm{W}$ & 2790 & IO1176-91 & $44^{\circ} 56,7^{\prime}$ & $15^{\circ} 02,9^{\prime} \mathrm{E}$ & 4649 \\
\hline R87-13 & $52^{\circ} 42,8^{\prime}$ & $36^{\circ} 59,3^{\prime} \mathrm{W}$ & 2020 & IO1277-2 & $45^{\circ} 02,1^{\prime}$ & $22^{\circ} 28,2^{\prime} \mathrm{E}$ & 4806 \\
\hline $37-14$ & $51^{\circ} 27,7^{\prime}$ & $34^{\circ} 00,5^{\prime} \mathrm{W}$ & 2600 & IO1277-8 & $50^{\circ} 32,5^{\prime}$ & $3,0^{\prime} \bar{E}$ & 4492 \\
\hline $88-01$ & $46^{\circ} 40,6^{\prime}$ & $9,2^{\prime} \mathrm{E}$ & 2925 & IO1277-12 & $54^{\circ} 00,6^{\prime}$ & $7,5^{\prime} \mathrm{E}$ & 3178 \\
\hline $38-02$ & $45^{\circ} 45,2^{\prime}$ &, $0^{\prime} \mathrm{E}$ & 3480 & IO1277-28 & $61^{\circ} 28,0^{\prime}$ & $1,0^{\prime} \mathrm{E}$ & 5322 \\
\hline $38-03$ & $46^{\circ} 04,1^{\prime}$ &, $7^{\prime} \mathrm{E}$ & 3400 & IO1277-41 & $69^{\circ} 59,9^{\prime}$ & $05^{\circ} 04,6^{\prime} \mathrm{W}$ & 1873 \\
\hline $8-04$ & $49^{\circ} 55,3^{\prime}$ & $100^{\circ} \mathrm{C}$ & 3350 & IO1578-49 & $61^{\circ} 05,6^{\prime}$ & $19^{\circ} 51,9^{\prime} \mathrm{W}$ & 4718 \\
\hline $8-05$ & $52^{\circ} 56,7^{\prime}$ & $109^{\circ}$ & 3510 & $101678-64$ & $54^{\circ} 00,5^{\prime}$ & $7 \mathrm{~W}$ & 4515 \\
\hline $8-06$ & $49^{\circ} 01,3^{\prime}$ & $128^{\circ} 4$ & 3850 & IO1678-80 & $47^{\circ} 57,0^{\prime}$ & $13^{\circ} 01,4^{\prime} \mathrm{W}$ & 3102 \\
\hline 8-07 & $47^{\circ} 08,9^{\prime}$ & $145^{\circ}$ & 2890 & $101678-84$ & $51^{\circ} 57,5^{\prime}$ & $14^{\circ} 2$ & 3952 \\
\hline $8-08$ & $49^{\circ} 15,7$ & $148^{\circ} 48,2^{\prime} \mathrm{E}$ & 3885 & IO1678-89 & $57^{\circ} 03,6^{\prime}$ & $18^{\circ} 32$ & 4285 \\
\hline $8-09$ & $50^{\circ} 35,6^{\prime}$ & $3 \mathrm{E}$ & 4350 & IO1678-96 & $60^{\circ} 27,9^{\prime}$ & $21^{\circ} 3$ & 4177 \\
\hline $8-10$ & $54^{\circ} 11,2^{\prime}$ & $144^{\circ} 4$ & 2785 & P1010 & $77^{\circ} 20,0^{\prime}$ & $35^{\circ} 0$ & 476 \\
\hline & ${ }^{\circ} 55,0^{\prime}$ & $144^{\circ} \mathrm{C}$ & 2880 & P1141 & $61^{\circ} 30,0^{\prime}$ & $63^{\circ} 30,0^{\prime} \mathrm{W}$ & 1417 \\
\hline & $23,8^{\prime}$ & $145^{\circ} 17,2^{\prime} \mathrm{E}$ & 3020 & P1147 & $61^{\circ} 40,0^{\prime}$ & $54^{\circ} 45$, & 2300 \\
\hline & 56,9 & $144^{\circ} 35,0^{\prime} \mathrm{E}$ & 3740 & P1160 & $61^{\circ} 00,0^{\prime}$ & $46^{\circ} 00,0^{\prime} \mathrm{W}$ & 320 \\
\hline $8-14$ & $61^{\circ} 16,8$ & $144^{\circ} 2$ & 4200 & P117 & $61^{\circ} 25,0^{\prime}$ & $47^{\circ} 0$ & 500 \\
\hline & $63^{\circ} 18,3^{\prime}$ & $141^{\circ} 5$ & 3880 & P1184 & $62^{\circ} 10,0^{\prime}$ & $57^{\circ} 1$ & 1882 \\
\hline & $64^{\circ} 46,2^{\prime}$ & $141^{\circ} 13,4^{\prime} \mathrm{E}$ & 3320 & P11s & $77^{\circ} 25,0^{\prime}$ & $39^{\circ} 0$ & 842 \\
\hline & $66^{\circ} 12,1^{\prime}$ & $140^{\circ} 30,2^{\prime} \mathrm{E}$ & 180 & P12 & $75^{\circ} 30,0^{\prime}$ & $57^{\circ} 0$ & 431 \\
\hline $8-18$ & $65^{\circ} 45,0^{\prime}$ & $138^{\circ} 12,0^{\prime} \mathrm{E}$ & 615 & P1223 & $76^{\circ} 00,0$ & $33^{\circ} 30,0^{\prime} \mathrm{W}$ & 772 \\
\hline & $64^{\circ} 34,3^{\prime}$ & $135^{\circ} 37,5^{\prime} \mathrm{E}$ & 2930 & PC82-35 & $62^{\circ} 21,7^{\prime}$ & $57^{\circ} 22,0^{\prime} \mathrm{W}$ & 1484 \\
\hline $8-20$ & $64^{\circ} 56,1^{\prime}$ & $129^{\circ} 0$ & 1670 & PC82-71 & $62^{\circ} 38,4^{\prime}$ & $59^{\circ} 32,0^{\prime} \mathrm{W}$ & 1350 \\
\hline & $64^{\circ} 49,3^{\prime}$ & $126^{\circ} 4$ & 2250 & PC82-136 & $64^{\circ} 35,4^{\prime}$ & $62^{\circ} 45,5^{\prime} \mathrm{W}$ & 452 \\
\hline R88-22 & $64^{\circ} 40,1^{\prime}$ & $119^{\circ} 3$ & 3140 & PC82-140 & $64^{\circ} 49,6^{\prime}$ & $62^{\circ} 37,8^{\prime} \mathrm{W}$ & 392 \\
\hline R88-23 & $63^{\circ} 18,0$ & $117^{\circ} 15,8^{\prime} \mathrm{E}$ & 3292 & PC82-197 & $63^{\circ} 43,0^{\prime}$ & $57^{\circ} 13,6^{\prime} \mathrm{W}$ & 750 \\
\hline KR88-24 & $63^{\circ} 44,8^{\prime}$ & $116^{\circ} 44,9^{\prime} \mathrm{E}$ & 2600 & DF83 III-11C & $78^{\circ} 15,0^{\prime}$ & $172^{\circ} 17,0^{\prime} \mathrm{W}$ & 430 \\
\hline KR88-25 & $64^{\circ} 17,9^{\prime}$ & $115^{\circ} 42,1^{\prime} \mathrm{E}$ & 2232 & DF83 III-12 & $78^{\circ} 16,0^{\prime}$ & $170^{\circ} 08,0^{\prime} \mathrm{W}$ & 541 \\
\hline KR88-27 & $63^{\circ} 39,1^{\prime}$ & $101^{\circ} 08,9^{\prime} \mathrm{E}$ & 1240 & DF83 III-19 & $77^{\circ} 18,0^{\prime}$ & $158^{\circ} 43,0^{\prime} \mathrm{W}$ & 677 \\
\hline KR88-28 & $64^{\circ} 09,5^{\prime}$ & $98^{\circ} 09,5^{\prime} \mathrm{E}$ & 1200 & DF83 III-41 & $76^{\circ} 40,0^{\prime}$ & $164^{\circ} 01,0^{\prime} \mathrm{W}$ & 516 \\
\hline $\mathrm{R} 88-29$ & $2^{\circ} 29,5^{\prime}$ & $95^{\circ} 5$ & 3790 & III-42 & $38,0^{\prime}$ & $0 . \mathrm{W}$ & 420 \\
\hline
\end{tabular}

MD: kullenberg from Marion-Dufresne; KR: box core from Marion-Dufresne; V: Vema; RC: Robert Conrad; IO: piston core from Islas Orcadas (cruises 11,12,15, and 16); P: box core from Polarstern; PC and DF: box core from U.S. Coast Guard Glacier. 


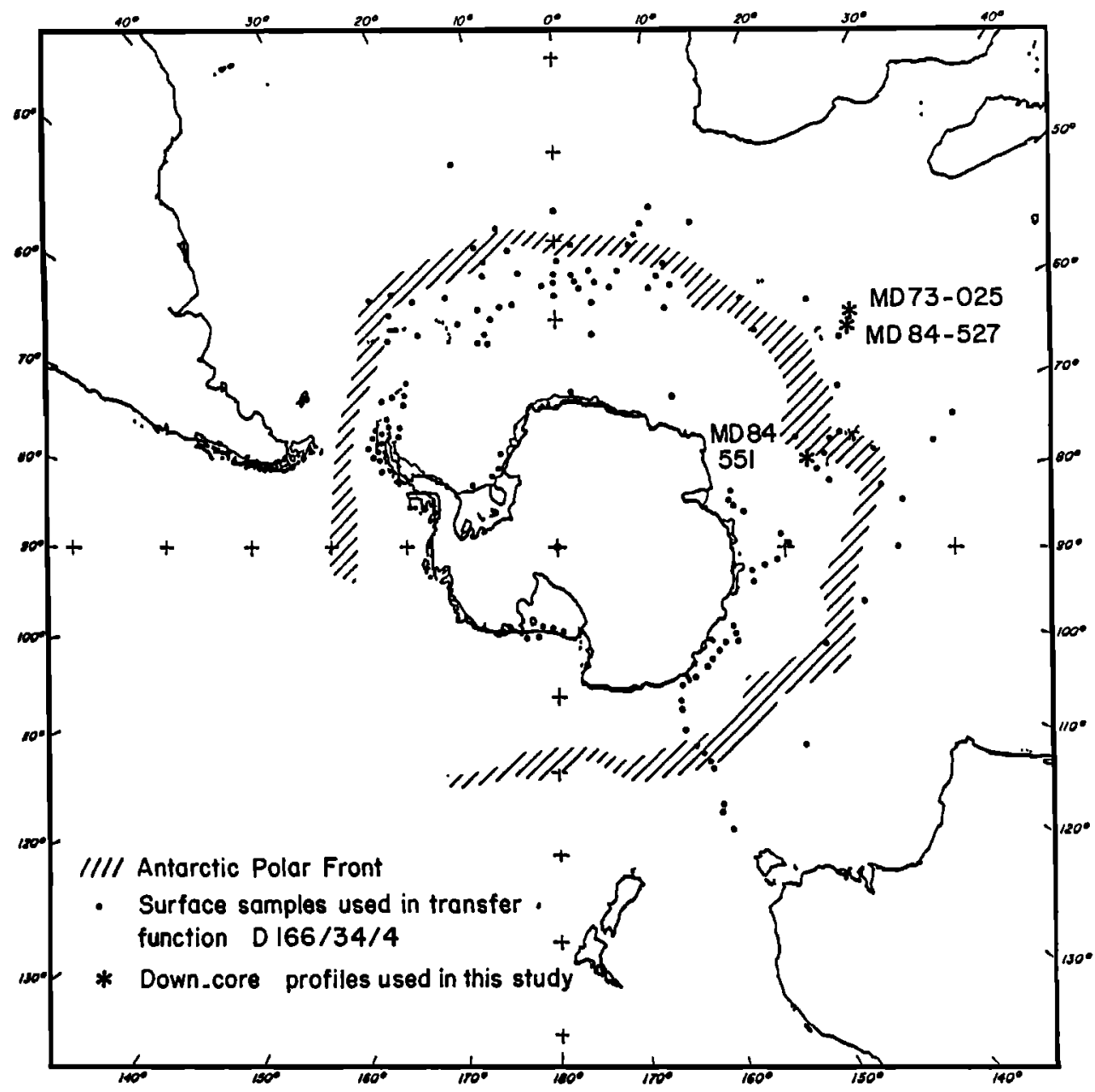

Fig. 1. Geographic distribution of 124 surface sediment samples and three core profiles used in this study. Location of the Antarctic Polar Front is taken from the reference data map of Gordon and Molinelli [1982].

non-reworked Holocene sediments. Forty-two samples with assemblages altered by step wise opal dissolution of five Holocene core tops [Pichon et al.,1992] were added to the natural floral data for the Q-mode factor analysis. Before the calculations, the floral counts were ranked in four abundance classes defined for each of the 34 species (Table 2, following Pichon et al., [1987]). This method increases considerably the sensitivity of the DTF for changes in SST. However, the separation between abundance class 1 (absent) and class 2 (present at low levels) has a heavy statistical weight for certain low abundance species. This may introduce an error exceeding the average standard error of the estimates. [Pichon et al., 1987].

The data, once ranked, were treated by the programs CABFAC, REGRESS and THREAD kindly provided by N. Kipp and adapted to the IBM 9121 of the Bordeaux I University Computer Center. Modern sea surface temperature estimates for summer, autumn, winter, and spring are 3- month averages (January-February-March,...) determined by interpolating values from reference data maps [Gordon and Molinelli, 1982].

\section{Results of Factor Analysis}

A Q-mode factor analysis of the 166 samples (124 core tops +42 partly dissolved samples) resolves four varimax factors (which accounts for $34 \%$, $30.2 \%, 12.6 \%$, and $6.6 \%$ of the total variance, respectively). Addition of a fifth factor accounts for $<2.4 \%$ of the variance and is unrelated to any discernible biogeographic, physical, or chemical influence. The varimax factor matrix gives the composition of each sample in terms of the four varimax factors (Table 3 ). We have plotted in Figures 2 to 5 the distribution of the loadings for each successive factor over our sample set; floral 
TABLE 2. Conversion of Relative Percentage Into Abundance Rank for Each Species

\begin{tabular}{llccc}
\hline & \multicolumn{4}{c}{ Rank Value } \\
\cline { 2 - 5 } \multicolumn{1}{c}{ Species } & 0 & 1 & 2 & 3 \\
\hline Actinocyclus actinochilus & 0 & 1 & $2-6 \%$ & $6.5-13 \%$ \\
Asteromphalus parvulus & 0 & 1 & 2 & 3 \\
Azpeitia tabularis & 0 & 1 & 2 & $2,5-5$ \\
Chaetoceros sp. & 0 & 1 & 2 & 3 \\
Cocconeis sp. & 0 & 1 & $2-4$ & $4.5-9$ \\
Coscinodiscus furcatus & 0 & 1 & $2-4$ & $4.5-9$ \\
Dictyocha genus* & 0 & 1 & $2-4$ & $5-10$ \\
Distephanus genus* & 0 & 1 & 2 & $2,5-5$ \\
Eucampia antarctica & 0 & 1 & $2-24$ & $25-50$ \\
Hemidiscus cuneiformis & 0 & 1 & $2-6$ & $6.5-13$ \\
Nitzschia curta & 0 & 1 & $2-31$ & $32-64$ \\
Nitzschia angulata & 0 & 1 & $2-5$ & $5.5-11$ \\
Nitzschia cyclindrus & 0 & 1 & $2-7$ & $8-16$ \\
Nitzschia kerguelensis & 0 & 1 & $2-40$ & $40.5-81$ \\
Nitzschia ritscherii & 0 & 1 & 2 & 3 \\
Nitzschia separanda & 0 & 1 & $2-3$ & $4-8$ \\
Nitzschia sublineata & 0 & 1 & $2-15$ & $16-32$ \\
Odontellia weissflogii & 0 & 1 & $2-8$ & $8.5-19$ \\
Porosira glacialis & 0 & 1 & $2-3$ & $4-8$ \\
Pseudoeunotia doliolus & 0 & 1 & $2-19$ & $19.5-39$ \\
Rhysosolenia styliformis & 0 & 1 & 2 & $3-6$ \\
Roperia tesselata & 0 & 1 & $2-5$ & $6-12$ \\
Thalassionema nitzschioides 0 & 1 & $2-4$ & $4.5-9$ \\
Thalassiosira antarctica & 0 & 1 & $2-30$ & $31-62$ \\
Thalassiosira decipiens & 0 & 1 & & \\
Thalassiosira delicatulata & 0 & 1 & & \\
Thalassiosira excentrica & 0 & 1 & & \\
Thalassiosira gracilis & 0 & 1 & $2-6$ & $7-14$ \\
Thalassiosira lentiginosa & 0 & 1 & $2-20$ & $20.5-41$ \\
Thalassiosira lineata & 0 & 1 & 2 & 3 \\
Thalassiosira oestrupii & 0 & 1 & $2-8$ & $8.5-17$ \\
Thalassiosira oliverana & 0 & 1 & 2 & $2.5-5$ \\
Thalassiosira tumida & 0 & 1 & 2 & $2.5-5$ \\
Thalassiothrix sp. & 0 & 1 & 2 & 3 \\
\hline & &
\end{tabular}

* silicoflagellate

contours have been interpolated between sample values. Each figure includes

1. A histogram illustrating the species composition of the factor as listed in the varimax factor score matrix (Table 4). The $X$ axis of the histograms follows the order of the species indexation constructed on factor 3 , to illustrate the temperature dependence from warmer (left) to cooler (right) species. This indexation is reported in the following discussion simultaneously with the species names.

2. A graph illustrating the distribution of the factor as a function of summer SST.

Factor 1 (Figure 2), which accounts for $34 \%$ of the total variance, is dominated by three endemic species, Thalassiothrix sp. 133, Nitzchia kerguelensis /10 and the silicoflagellate Distephanus speculum $/ 16$, where the bold-faced digits represent the index number of each species (Table 4). High abundance and good preservation characterize this assemblage. It defines a diatom-ooze surfacesediment belt centered on $\sim 55^{\circ} \mathrm{S}$, and will be referred as the "open-ocean Antarctic" assemblage. The 0.6 factor loading boundary falls between the $4^{\circ}$ and $6^{\circ} \mathrm{C}$ summer isotherms to the north, a few degrees north of the Antarctic Polar Front (APF). The southern limit coincides with the $+1^{\circ} \mathrm{C}$ summer isotherm.

Factor 2 (Figure 3) accounts for $30.2 \%$ of the total variance. It is composed of Thalassiosira antarctica (resting spores)/ 11 , four epontic species (i.e., including attached and non-attached species especially adapted to the ice habitat: Nitzschia curta 131 , Actinocyclus actinochilus $/ 28$, Nitzchia sublineata 134, Nitzschia cylindrus /22), and Eucampia antarctica (winter stage)/18. This assemblage is referred to the "Ice-Zone Antarctic" assemblage, and extends along the Ross (Ross Sea), Filchner and Ronne (Weddell Sea) ice shelves, around the Antarctic Peninsula and near the Antarctic coast. It represents cold $\left(<1^{\circ} \mathrm{C}\right)$ and low-salinity waters.

Factor 3 (Figure 4 ) accounts for $12.6 \%$ of the total variance. The Subantarctic species Thalassionema nitzschioides $/ 1$, Roperia tesselata $/ 3$, Hemidiscus cuneiformis 15 , and the silicofagellate Dictyocha sp. 13 dominate this assemblage. Numerous others Subantarctic species are also present as minor constituents. It covers the entire northern portion of the area studied and is referred to as the "Subantarctic" assemblage. The southern 0.6 factor-loading limit lies a few degrees north of the actual position of the APF. This factor shows the highest correlation $(r=0.92)$ to summer SST, suggesting that it is the most purely temperaturedependent of the factors.

Factor 4 (Figure 5), which contributes $6.6 \%$ of the total variance is dominated by $T$. lentiginosa $/ 6$, $N$. kerguelensis /10 and E. antarctica (resting spores)/18. The geographic distribution of samples with loadings $<-0.3$ is patchy with no definite pattern. The highest negative loadings of this assemblage appear in high-dissolution samples (Table 3). Shemesh et al. [1989] and Pichon et al. [1992] indicate that these three species are highly resistant to dissolution. There is no significant correlation of factor 4 with SST $(R=0.25)$, which confirms that the five Holocene core tops that were used to build the partially dissolved reference samples were effectively well representative of the SST's distribution. Factor 4 is well correlated $(R=$ 0.90 ) in the artificially-dissolved samples with the amount of dissolved silica [Bareille et al., 1991; Pichon et al., 1991]. This assemblage can thus be referred to as a "Sediment dissolution" assemblage. 
TABLE 3. Varimax Factor Matrix

\begin{tabular}{|c|c|c|c|c|c|c|c|c|c|c|c|c|}
\hline ore & om. & 1 & F. 2 & $\mathbf{F}$ & F. 4 & Core & SST & Com. & F. 1 & F. 2 & F. 3 & F. 4 \\
\hline MD24-KK02 & $\begin{array}{ll}1,5 & 0,8\end{array}$ & $\overline{0,72}$ & 0,48 & 0,16 & $-0,14$ & RC13-272 & 0,8 & 0,89 & $\overline{0,74}$ & 0,54 & 0,08 & $-0,22$ \\
\hline MD24-KK32 & $1,2 \quad 0,86$ & 0,81 & 0,33 & 0,27 & $-0,16$ & $\mathrm{RC} 13-273$ & 1,0 & 0,8 & 0,75 & 0,45 & 0,13 & $-0,16$ \\
\hline MD24-KK35 & $\begin{array}{ll}1,8 & 0,87\end{array}$ & 0,80 & 0,35 & 0,25 & $-0,22$ & $\mathrm{RC} 13-274$ & 1,8 & 0,87 & 0,75 & 0,49 & 0,13 & $-0,22$ \\
\hline MD24-KK37 & $2,0 \quad 0,83$ & 0,84 & 0,32 & 0,13 & $-0,11$ & RC15-91 & 4,8 & 0,84 & 0,68 & 0,18 & 0,51 & $-0,29$ \\
\hline MD24-KK63 & $3,2 \quad 0,86$ & 0,84 & 0,19 & 0,33 & $-0,01$ & RC17-56 & 1,0 & 0,76 & 0,49 & 0,61 & 0,11 & $-0,38$ \\
\hline MD73-026 & $\begin{array}{ll}8,0 & 0,83\end{array}$ & 0,64 & 0,13 & 0,63 & $-0,10$ & 1176 & 1,0 & 0,81 & 0,74 & 0,46 & 0,19 & $-0,15$ \\
\hline MD82-424 & 0,88 & 0,85 & 0,37 & & $-0,05$ & 117 & & 0,85 & 0,79 & 0,46 & 0,06 & $-0,10$ \\
\hline-425 & $0,8 \quad 0,85$ & 0,79 & 0,37 & 0,20 & $-0,21$ & & 4,5 & 0,88 & 0,86 & 0,16 & 0,30 & $-0,15$ \\
\hline-430 & $0,5 \quad 0,91$ & 0,72 & 0,48 & 0,24 & $-0,32$ & 117 & 6,0 & 0,84 & 0,77 & 0,16 & 0,47 & $-0,04$ \\
\hline MD82-434 & $0,5 \quad 0,92$ & 0,78 & 0,53 & 0,07 & $-0,16$ & 117 & 6,0 & 0,82 & 0,55 & 0,24 & 0,64 & $-0,23$ \\
\hline-436 & $\begin{array}{ll}0,0 & 0,77\end{array}$ & 0,60 & 0,56 & 0,17 & $-0,25$ & 117 & 8,0 & 0,81 & 0,45 & 0,13 & 0,77 & $-0,01$ \\
\hline 529 & $5,5 \quad 0,91$ & 0,82 & 0,15 & 0,45 & $-0,05$ & 127 & 8,5 & 0,81 & 0,47 & 0,13 & 0,74 & $-0,09$ \\
\hline MD8 & $\begin{array}{lll}0,0 & 0,85\end{array}$ & 0,53 & 0,66 & 0,17 & $-0,33$ & 127 & 1,8 & 0,76 & 0,65 & 0,36 & 0,26 & $-0,37$ \\
\hline & $\begin{array}{ll}-0,5 & 0,84\end{array}$ & 0,23 & 0,87 & 0,06 & $-0,17$ & & 1,5 & 0,72 & 0,68 & 0,39 & 0,24 & $-0,21$ \\
\hline $\mathrm{MD}$ & $\begin{array}{lll}0,2 & 0,89\end{array}$ & 0,46 & 0,71 & 0,10 & $-0,41$ & 127 & 0,5 & 0,85 & 0,71 & 0,54 & 0,03 & $-0,23$ \\
\hline 33 & $\begin{array}{ll}1,0 & 0,91\end{array}$ & 0,53 & 0,62 & 0,19 & $-0,46$ & 127 & $-1,0$ & 0,87 & 0,34 & 0,74 & 0,12 & $-0,44$ \\
\hline MD8 & $1,20,85$ & 0,72 & 0,50 & 0,18 & $-0,21$ & 157 & 0,0 & 0,9 & 0,59 & 0,59 & 0,18 & $-0,42$ \\
\hline & $2,5 \quad 0,84$ & 0,85 & 0,22 & 0,27 & $-0,02$ & 167 & 2,0 & 0,85 & 0,65 & 0,39 & 0,41 & $-0,33$ \\
\hline & $2,3 \quad 0,89$ & 0,86 & 0,24 & 0,28 & $-0,09$ & 167 & 6,0 & 0,81 & 0,68 & 0,22 & 0,51 & $-0,21$ \\
\hline & $\begin{array}{ll}3,5 & 0,79\end{array}$ & 0,73 & 0,34 & 0,38 & 0,06 & & 3,5 & 0,82 & 0,69 & 0,36 & 0,38 & $-0,26$ \\
\hline & $\begin{array}{ll}4,5 & 0,89\end{array}$ & 0,80 & 0,21 & 0,42 & $-0,13$ & & 1,0 & 0,81 & 0,68 & 0,54 & 0,10 & $-0,20$ \\
\hline & $\begin{array}{ll}5,0 & 0,85\end{array}$ & 0,79 & 0,21 & 0,43 & $-0,02$ & & 0,0 & 0,85 & 0,78 & 0,47 & 0,15 & $-0,09$ \\
\hline MD & $\begin{array}{lll}5,0 & 0,68\end{array}$ & 0,54 & 0,38 & 0,50 & 0,00 & 101 & $-1,8$ & 0,68 & $-0,06$ & 0,80 & $-0,03$ & $-0,19$ \\
\hline KR87 & $\begin{array}{ll}1,5 & 0,77\end{array}$ & 0,65 & 0,53 & 0,24 & $-0,11$ & 114 & 0,0 & 0,84 & $-0,10$ & 0,90 & 0,11 & 0,03 \\
\hline & $2,0 \quad 0,92$ & 0,68 & 0,63 & 0,26 & $-0,02$ & 114 & 0,0 & 0,85 & 0,06 & 0,91 & 0,13 & $-0,05$ \\
\hline & $1,0 \quad 0,92$ & 0,38 & 0,87 & 0,15 & 0,00 & & 0,0 & 0,84 & 0,18 & 0,89 & 0,13 & 0,03 \\
\hline & 1,0 & 0,47 & 0,74 & 0,22 & $-0,34$ & & 0,0 & 0,82 & 0,24 & 0,86 & 15 & 0,02 \\
\hline & $1,8 \quad 0,86$ & 0,49 & 0,77 & 0,18 & 0,06 & 118 & 0,0 & 0,83 & 0,11 & 0,89 & 0,11 & 0,08 \\
\hline & $0,5 \quad 0,89$ & 0,19 & 0,91 & 0,18 & 0,01 & & $-1,8$ & 0,59 & 0,01 & 0,69 & $-0,06$ & $-0,34$ \\
\hline & $1,0 \quad 0,82$ & 0,47 & 0,64 & 0,16 & $-0,40$ & 121 & $-1,8$ & 0,66 & 0,02 & 0,71 & $-0,07$ & $-0,39$ \\
\hline $\mathrm{KR}$ & $1,8 \quad 0,85$ & 0,52 & 0,71 & 0,25 & $-0,09$ & 122 & $-1,8$ & 0,6 & 0,18 & 0,73 & $-0,04$ & $-0,19$ \\
\hline & $3,0 \quad 0,9$ & 0,59 & 0,59 & 0,37 & $-0,28$ & PC8 & 0,0 & 0,88 & 0,33 & 0,86 & 0,14 & 0,10 \\
\hline & $3,0 \quad 0,62$ & 0,53 & 0,51 & 0,25 & $-0,11$ & $\mathrm{PC}$ & 0,0 & 0,86 & 0,33 & 0,83 & 0,17 & 0,17 \\
\hline & 4,5 & 0,62 & 0,45 & 0,26 & 01 & & 0,0 & 0,86 & 0,18 & 0,89 & 0,16 & $-0,06$ \\
\hline & $8,5 \quad 0,83$ & 0,53 & 0,32 & 0,65 & $-0,1$ & & 0,0 & 0,82 & 0,14 & 0,88 & 0,16 & $-0,05$ \\
\hline & $9,20,8$ & 0,57 & 0,29 & 0,58 & $-0,2$ & & 0,0 & 0,8 & 0,01 & 87 & 16 & $-0,11$ \\
\hline & 9,00 & 0,55 & 0,23 & 0,70 & $-0,1$ & DF & $-1,9$ & 0,69 & 0,18 & 0,81 & $-0,04$ & $-0,05$ \\
\hline & $6,0 \quad 0,85$ & 0,70 & 0,15 & 0,56 & $-0,18$ & DF & $-1,9$ & 0,74 & 0,22 & 0,79 & 0,08 & $-0,25$ \\
\hline & $3,5 \quad 0,88$ & 0,78 & 0,35 & 0,35 & $-0,14$ & DF8 & $-1,9$ & 0,73 & 0,09 & 0,84 & 0,02 & $-0,12$ \\
\hline KR8 & $9,8 \quad 0,85$ & 0,23 & 0,10 & 0,87 & $-0,17$ & DF8: & $-1,9$ & 0,73 & 0,25 & 0,79 & $-0,06$ & $-0,22$ \\
\hline KR8 & 11,0 & 0,20 & 0,02 & 0,86 & $-0,21$ & DF8 & $-1,9$ & 0,77 & 0,24 & 0,84 & $-0,08$ & $-0,07$ \\
\hline & $\begin{array}{lll}10,0 & 0,87\end{array}$ & 0,45 & 0,11 & 0,79 & $-0,20$ & & 2,0 & 0,94 & 0,69 & 0,61 & 0,29 & $-0,04$ \\
\hline & $\begin{array}{lll}9,0 & 0,84\end{array}$ & 0,50 & 0,16 & 0,72 & $-0,21$ & & 2,0 & 0,91 & 0,68 & 0,61 & 0,28 & 0,03 \\
\hline & $, 50,89$ & 0,84 & 0,16 & 0,41 & -0 & & 2,0 & 0,89 & 0,63 & 0,60 & 0,25 & 0,26 \\
\hline & $0 \quad 0,92$ & 0,89 & 0,14 & 0,32 & -0, & & 2,0 & 0,86 & 0,65 & 0,61 & 0,26 & 0,03 \\
\hline & $4,5 \quad 0,83$ & 0,80 & 0,18 & 0,37 & -0 & & 2,0 & 0,89 & 0,64 & 0,61 & 0,33 & 0,03 \\
\hline & $3,9 \quad 0,85$ & 0,84 & & 0,31 & -0 , & $-120^{\prime}$ & 2,0 & 0,86 & 0,64 & 0,64 & 0,20 & $-0,07$ \\
\hline & $\begin{array}{ll}1,8 & 0,89\end{array}$ & 0,84 & 0,30 & 0,24 & $-0,18$ & $-180^{\prime}$ & 2,0 & 0,88 & 0,65 & 0,59 & 0,31 & $-0,12$ \\
\hline & $1,0 \quad 0,86$ & 0,71 & 0,44 & 0,14 & $-0,37$ & D8702-240' & 2,0 & 0,62 & 0,60 & 0,41 & 0,31 & 0,05 \\
\hline & $\begin{array}{lll}0,0 & 0,87\end{array}$ & 0,54 & 0,52 & 0,21 & $-0,51$ & D8702-24H & 2,0 & 0,77 & 0,35 & 0,41 & 0,34 & $-0,60$ \\
\hline & $\begin{array}{lll}-1,0 & 0,86\end{array}$ & 0,25 & 0,87 & 0,10 & $-0,18$ & D8707-5' & 0,5 & 0,94 & 0,23 & 0,92 & 0,20 & 0,02 \\
\hline
\end{tabular}


TABLE 3. (continued)

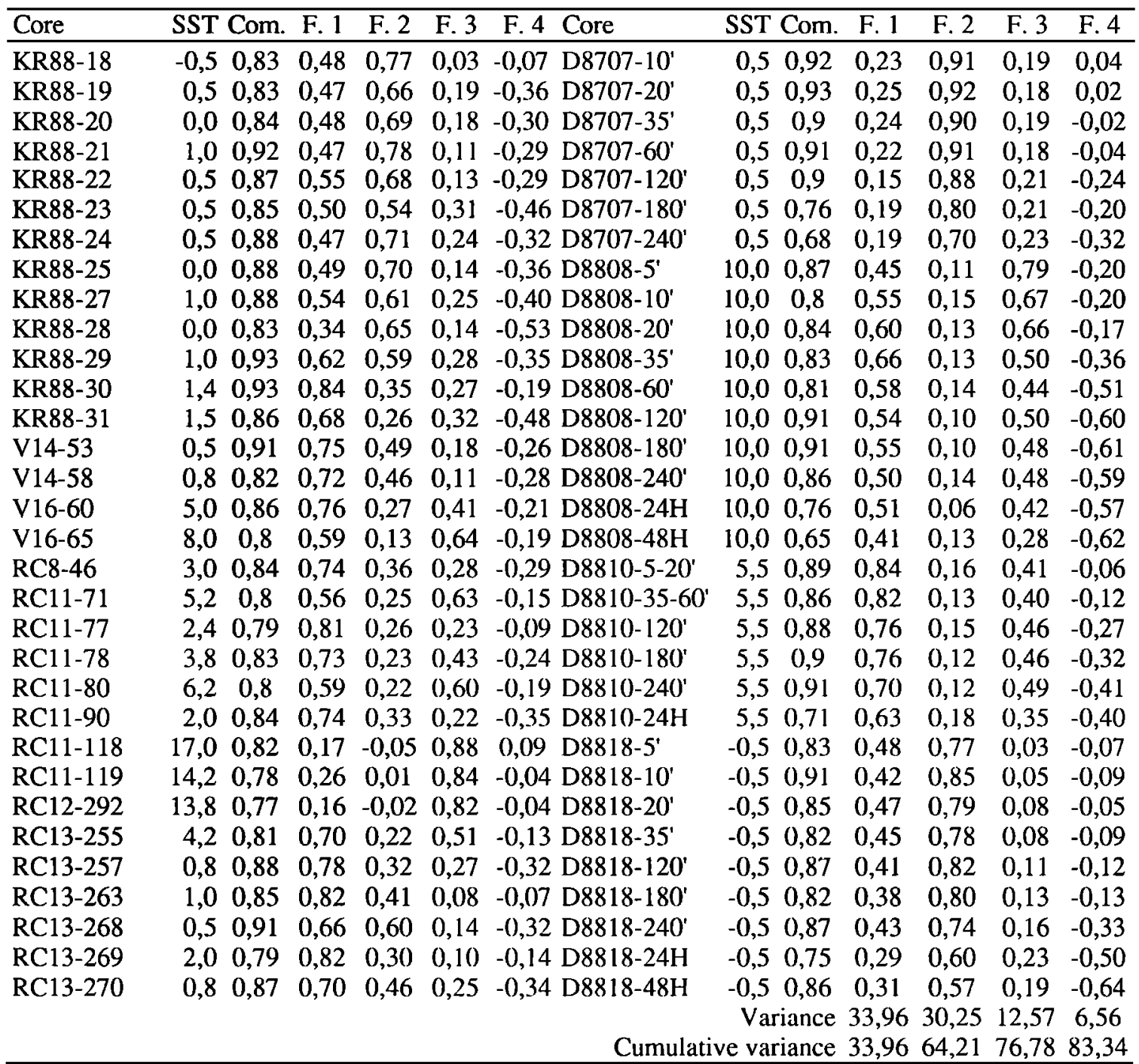

SST: summer sea surface temperature; Com.: communality; D: Dissolved samples.

\section{Discussion}

Figure 6 displays the general distribution of the three biogeographic factors. Despite the critical role played by dissolution in the water column, this distribution follows the general circumpolar symmetry of the plankton diatom biocoenosis [Baker, 1948]. It is important to recognize that modern diatom floras are affected by a number of interrelated factors including light, temperature, nutrients, and water column structure and stability [Leventer and Pichon, 1991]. The Subantarctic water appears to be a region of mixing between the Antarctic and the temperate/subtropical diatom floras
[Hendey, 1937; Hart, 1942; Boden, 1949; Fukase, 1962; Hargraves, 1968; Hasle, 1969; Donahue, 1970; and Fenner et al., 1976]. The open ocean zone contains a more heterogeneous group [Hargraves, 1968]. The characteristic species are occasionally found north of the APF or in the pack-ice but are probably not successful there. Donahue [1970] found in the phytoplankton the species Nitzchia kerguelensis /10 to be one of the most eurythermal Antarctic diatoms $\left(-1^{\circ}\right.$ to $13^{\circ} \mathrm{C}$ summer SST).

In the ice zone, Thalassiosira and Nitzchia genera are not only adapted to cold waters but also directly associated with the ice [Kozlova, 1966; Fryxell and Kendrick, 1988; El Sayed, 1971; Quilty, 
TABLE 4. Varimax Factor Score Matrix

\begin{tabular}{|c|c|c|c|c|c|}
\hline Species & Inde & & & ctor & \\
\hline & & 1 & 2 & 3 & 4 \\
\hline A. actinochilus & 28 & -0.086 & 0.379 & -0.051 & -0.134 \\
\hline A. parvulus & 26 & 0.176 & 0.022 & -0.044 & $0.0^{\prime}$ \\
\hline A. tabularis & 2 & 0.226 & & & -0.0 \\
\hline haetoce & 27 & 0.0 & & -0.045 & 0.039 \\
\hline occone & 14 & 0.080 & 203 & 0.100 & 0.158 \\
\hline furco & 20 & 0.011 & 0.073 & 0.050 & 0.081 \\
\hline Dictyoch & 4 & -0.102 & 0.009 & 0.344 & 0.073 \\
\hline istepha & 16 & 0.269 & 0.063 & 0.083 & 0.230 \\
\hline antar & 18 & 0.119 & 0.242 & 0.059 & -0.247 \\
\hline cunel & 5 & -0.102 & 0.005 & 0.285 & 0.036 \\
\hline curta & 31 & -0.075 & 0.381 & -0.082 & -0.05 \\
\hline & 30 & 0.044 & 0.215 & -0.067 & 0.076 \\
\hline cyli & 22 & -0.105 & 0.242 & 0.022 & 0.032 \\
\hline kerg & 10 & 0.427 & 0.075 & 0.132 & -0.335 \\
\hline . ritsch & 8 & 0.023 & -0.019 & 0.169 & 0.070 \\
\hline . separ & 32 & 0.227 & 0.045 & -0.086 & 0.055 \\
\hline subll & 34 & 0.040 & 0.33 & -0.16 & $-0.20 t$ \\
\hline & 13 & -0.036 & 0.182 & 0.105 & 0.176 \\
\hline P. glacic & 17 & -0.087 & 0.231 & 0.082 & 0.124 \\
\hline P. dolio & 9 & -0.054 & 0.006 & 0.134 & 0.027 \\
\hline & 12 & 0.103 & 0.203 & 0.112 & 0.317 \\
\hline & 3 & -0.116 & 0.007 & 0.345 & 0.056 \\
\hline nitz & 1 & 0.005 & -0.055 & 0.412 & 0.083 \\
\hline ant & 11 & -0.167 & 0.392 & 0.130 & 0.043 \\
\hline T. decip & 19 & 0.030 & -0.009 & 0.055 & 0.033 \\
\hline T. delice & 2 & 0.015 & 0.007 & 0.019 & -0.012 \\
\hline$i c a$ & 21 & 060 & -0.002 & 0.035 & 0.027 \\
\hline & 25 & 0.239 & 0.236 & -0.011 & 0.237 \\
\hline T. lent & & & & 0.254 & -0.519 \\
\hline T. line & 15 & & & 0.092 & 46 \\
\hline & 7 & -0.05 & -0.007 & 0.247 & 0.052 \\
\hline & 29 & 0.198 & 0031 & -0.05 & -0.182 \\
\hline turnáa & 2 & -0.001 & 0.057 & 0.016 & 0.053 \\
\hline halassiothri & 33 & 0.566 & 0.01 & -0.127 & 0.346 \\
\hline
\end{tabular}

The "temperature-related" index used in the text is reported with the corresponding species.

et al., 1985]. However, the preferential dissolution of the lightly silicified species that dominate the sea ice (including $N$. curta /31) is the major factor to consider in explaining the thanatocoenosis [Krebs, 1977], although resuspended and/or advected diatoms resulting from several years of production have also been collected in sediment traps [Leventer and Dunbar, 1987].

If deep themohaline current flow is sufficiently strong in many regions to be an important processes in advecting sediment components [Jones and Johnson, 1984], from our data the three distinct biogeographic assemblages of diatoms are also characteristic of plankton assemblages in overlying
Antarctic waters [Fenner et al., 1976]. So, the redistribution of diatoms by bottom waters cannot affect the results of this study.

Little is known about seasonal variability of Antarctic planktonic diatoms. The seasonal cycle of phytoplankton production shows a spring increase in November and December, with maximum values reached in December. Phytoplankton abundance drops off in January and February and then shows a small March and April increase in the northern part of the southern ocean. In May, the population drops to the winter minimum. This minimum persists until November, with a generally high temporal and spatial variability of the biogenic opal fluxes [Hart, 1942; Wefer et al., 1988, 1990].

From our sedimentary data the reasonably close correlations (Figure 6) of the first three factors with summer SST are clear and illustrate the succession of species dominance from $-1.9^{\circ} \mathrm{C}$ to $17^{\circ} \mathrm{C}$.

\section{Results of the Regression Analysis}

Following Imbrie and Kipp [1971], we have used a multiple curvilinear regression to quantify the relationships between the four floral factors in each of the 166 sediment samples and the present-day SST for summer, winter, autumn, and spring. Because of the great symmetry in the hydrology around Antarctica, these parameters are interdependent (Table 5). Summer SST is highly correlated (correlation coefficient $>0.96$ ) with the water temperatures of the other seasons which therefore may not be independently estimated. The relationships between each of the factors and the environmental parameters show the highest multiple correlation between Factor 3 and Summer SST (0.906). We present in Table 6 the regression results for all parameters, but we will discuss only the summer SST relation. The DTF has a multiple correlation coefficient (MCC) of 0.966 and a standard error of the estimate (SEE) of $\pm 1^{\circ} \mathrm{C}$, approximately $8 \%$ of the observed range of summer SST. Regression coefficients of the variables, intercepts for the curvilinear equations for summer (Table 6), and the varimax factor score matrix from the factor analysis (Table 4) define DTF 166/34/4.

The scatter diagram of observed versus estimated summer SST (Figure 7) indicates that DTF 166/34/4 accurately reconstructs temperature gradients between $-1.9^{\circ}$ and $10^{\circ} \mathrm{C}$. The few reconstructions available for the $10^{\circ}$ to $14^{\circ} \mathrm{C}$ summer SST range are also acceptable.

\section{Tests of Accuracy}

Three tests of accuracy may be used here to measure the validity of our SST estimates: (1) examination of residuals in the 42 artificial samples introduced in the DTF, (2) examination of core top samples that were eliminated from the initial floral data base because of their poor preservation and, (3) 


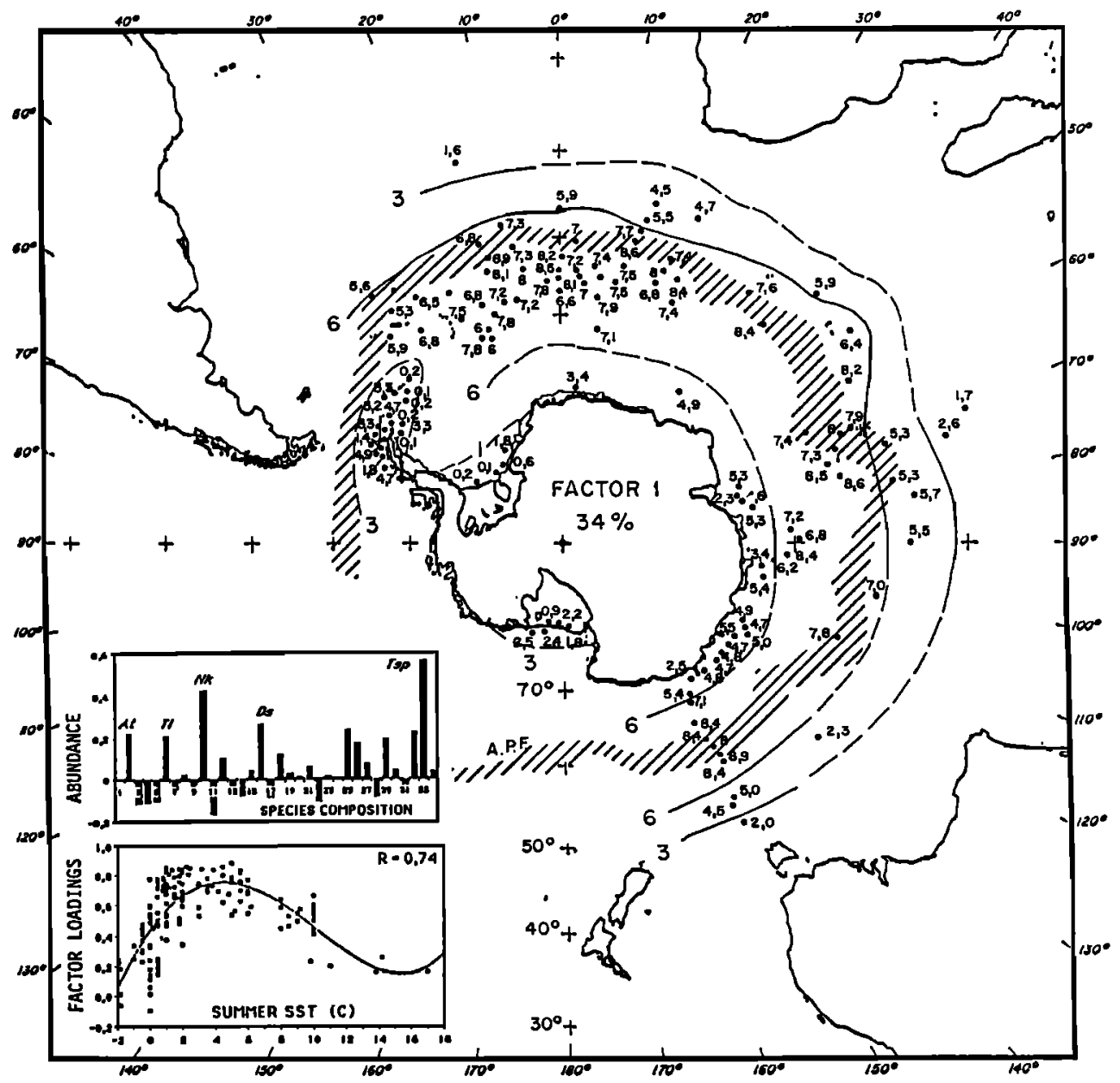

Fig. 2. "Open-ocean Antarctic" assemblage in surface sediments of the southern ocean (factor 1 loading boundaries $\mathrm{x} 10$ ). Histogram illustrates species composition of this assemblage from Table 4. X-Y graph illustrates generalized distribution of this assemblage with respect to summer SST from Gordon and Molinelli [1982].

comparison between foraminifera- and diatom-based equations in down core analysis.

Study of the residuals in the artificial samples (i.e., the differences obtained when the estimated temperatures are subtracted from the measured temperatures (Figure 8)) indicates that because of the selective dissolution of warmer diatom species, DTF $166 / 34 / 4$ underestimates SST by more than one standard error (residuals $>+1^{\circ} \mathrm{C}$ ) where dissolution is higher than $50 \%$ (factor 4 loadings $<-0.140$ ) for the Subantarctic zone samples. Simultaneously, due to the fragility of species associated with sea ice, the tendency is to overestimate the temperatures (residuals $<-1^{\circ} \mathrm{C}$ ) in samples located to the south of the APF that have experienced more than $80 \%$ dissolution (factor 4 loadings $<-0.300$ ). In these cases, high factor 4 scores may be used as dissolution indices (Table 3).

This test was extended to 23 core tops that had been excluded from the reference data base because of their poor preservation. Study of the residuals (Table 7, Figure 9) indicates that temperature estimates are within $\pm 1^{\circ} \mathrm{C}$ as long as estimated silica loss is less than $\sim 70 \%$ (factor 4 loadings $<-0.3$ ).

The relationship between accuracy as judged by the residuals and biogenic opal dissolution estimated by the factor 4 loadings can also be used to determine how diatom preservation may affect accuracy of downcore analyses. Because factor 4 is statistically independent of SST over the whole range -1.9 to $+10^{\circ} \mathrm{C}$, it may be used in paleoclimatic reconstructions as a quantitative opal dissolution estimator [Bareille et al., 1991; Pichon et al., 1992].

The reliability of SST estimates can be checked using equations calibrated with the distributions of different microfossils. Such a comparison is feasible for the Holocene in the Subantarctic zone using summer SST estimates based on foraminifera. The foraminifera-based equations used in this reconstruction are derived from the analysis of 


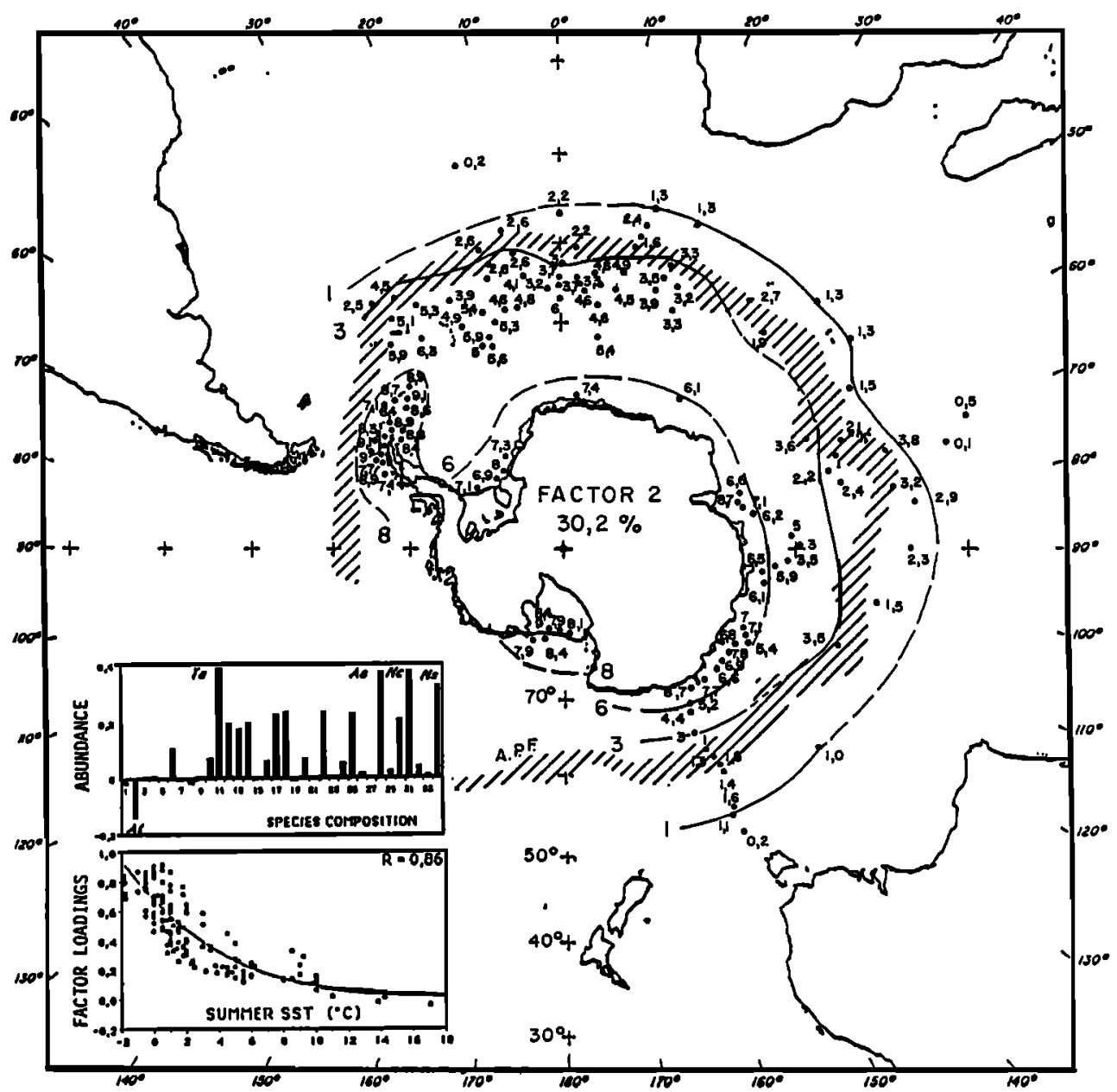

Fig. 3. "Ice zone Antarctic" assemblage in surface sediments of the southern ocean (factor 2 loading boundaries $\mathbf{x} 10)$. Histogram illustrates species composition of this assemblage from Table 4. X-Y graph illustrates generalized distribution of this assemblage with respect to summer SST from Gordon and Molinelli [1982].

census data for 21 species from 49 Indian Ocean surface-sediment samples [Labracherie et al., 1989]. The standard error for summer SST is $\pm 1.3^{\circ} \mathrm{C}$ over the range $+3^{\circ} \mathrm{C}$ to $+15.5^{\circ} \mathrm{C}$. Comparison of estimates made on the same samples using the two fossil groups is possible in 34 samples covering the last 14 kyr of core MD 84-527 [Labracherie et al., 1989]. Summer SST estimated by both transfer functions are identical within their standard error (Figure 10). The above results indicate that DTF 136/34/4 can be used to estimate accurately past changes in summer SST over a wide variety of samples.

\section{PALEOCLIMATIC RECORDS}

Core MD 84-527 is located between the Subtropical Convergence and the Antarctic Polar Front $\left(43^{\circ} 49^{\prime} 3 \mathrm{~S}-51^{\circ} 19^{\prime} 1 \mathrm{E}\right)$. It is a duplicate of over sampled core MD 73-025, a reference record for benthic foraminiferal isotopic changes [Duplessy et al., 1980; Labeyrie and Duplessy, 1985; Labeyrie et al., 1986; CLIMAP Project Members, 1984]; core MD 84-551 is located at $55^{\circ} 00^{\prime} 5 \mathrm{~S}, 73^{\circ} 16^{\prime} 9 \mathrm{E}$, within Antarctic waters (Figure 1).

\section{Foraminiferal Isotopic Analysis}

We have analyzed the oxygen and carbon isotopic ratio of both planktonic (Neogloboquadrina pachyderma s.) and benthic (Cibicides wuellerstorfi) foraminiferal species in core MD 84-527. At a few levels, Melonis barleeanum was analyzed where $C$. wuellerstorfi was absent. Because of a lack of benthic foraminifera, $N$. pachyderma $s$. was the only species analyzed in core MD 84-551. Isotopic ratios were measured at Gif on a manual VG-602 Isogas mass spectrometer, except for few recent analysis made on an automated MAT-251 Finnigan 


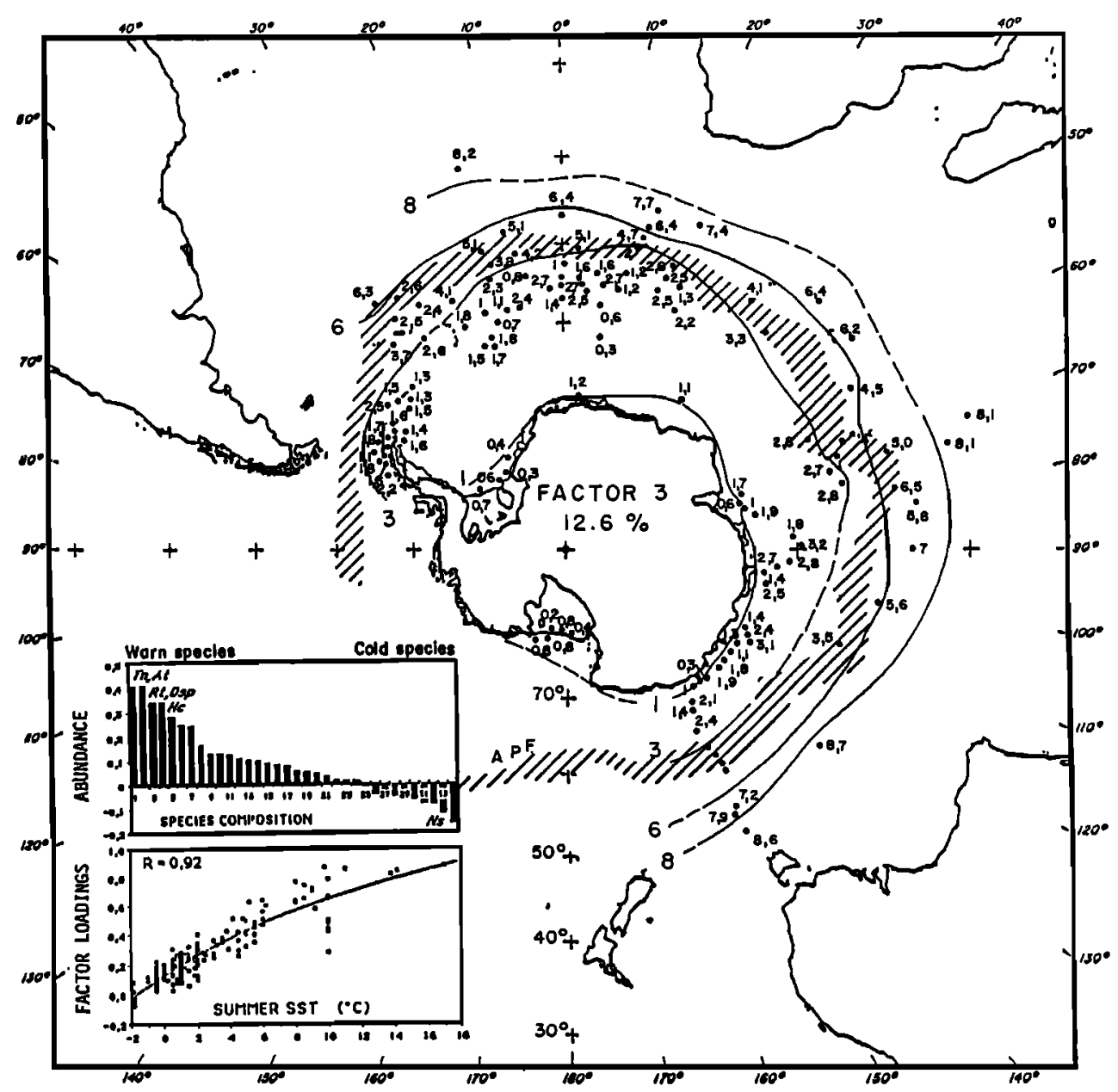

Fig. 4. "Subantarctic" assemblage in surface sediments of the southern ocean (factor 3 loading boundaries $\mathbf{x} 10$ ). Histogram illustrates species composition of this assemblage from Table 4. X-Y graph illustrates generalized distribution of this assemblage with respect to summer SST from Gordon and Molinelli [1982].

with individual acid reactors. External reproducibility at the $1 \mathrm{~s}$ level for individual analysis of standards ( $\delta^{18} \mathrm{O}$ and $\delta^{13} \mathrm{C}$ ) is $\pm 0.08 \%$ for the VG- 602 , and \pm $0.05 \%$ for the MAT-251 The measurements are reported as $\delta^{18} \mathrm{O}$ and $\delta^{13} \mathrm{C}$ referenced to the Pee Dee Belemnite standard versus depth for each core in Tables $8 \mathrm{a}$ and $8 \mathrm{~b}$, and Figure 11.

The $N$. pachyderma s. $\delta^{18} \mathrm{O}$ records of cores MD 84-527 and $M D$ 84-551 (c and $f$ in Fig. 11) cannot be directly compared to "standard" oxygen isotope signals, as given for example by Imbrie et al. [1984], Labeyrie et al. [1987], and Martinson et al. [1987]. Such is the case in most high latitude records: changes in surface temperature and salinity are large, with significant local variability, and sedimentation rates are deeply modulated by glacialinterglacial cycles (with a large decrease in diatom productivity both north and south of the subpolar zone and the addition of ice-rafted detritus). Planktonic foraminiferal $\delta^{18} \mathrm{O}$ is also sensitive to the occurrence of spikes of isotopically light meltwater during periods of deglaciation [Labeyrie et al., 1986]. The main isotopic transitions reported in Figure 11 are therefore defined from the benthic $\delta^{18} \mathrm{O}$ record of core MD 84-527, the $N$. pachyderma s. $\delta^{13} \mathrm{C}$ records [Labeyrie and Duplessy, 1985], and detailed covariance between the $N$. pachydermas. $\delta^{18} \mathrm{O}$ signals of both cores.

Compared to the general structure of lowerlatitude records [Martinson et al., 1987], the main characteristics of the $N$. pachyderma s. records are: a well-pronounced low $\delta^{18} \mathrm{O}$ at the beginning of isotope stage 5.5 , followed by a relatively sharp increase in $\delta^{18} \mathrm{O}$; the absence of well-defined $\delta^{18} \mathrm{O}$ oscillations during isotope stages 4 to 5.3 ; several 


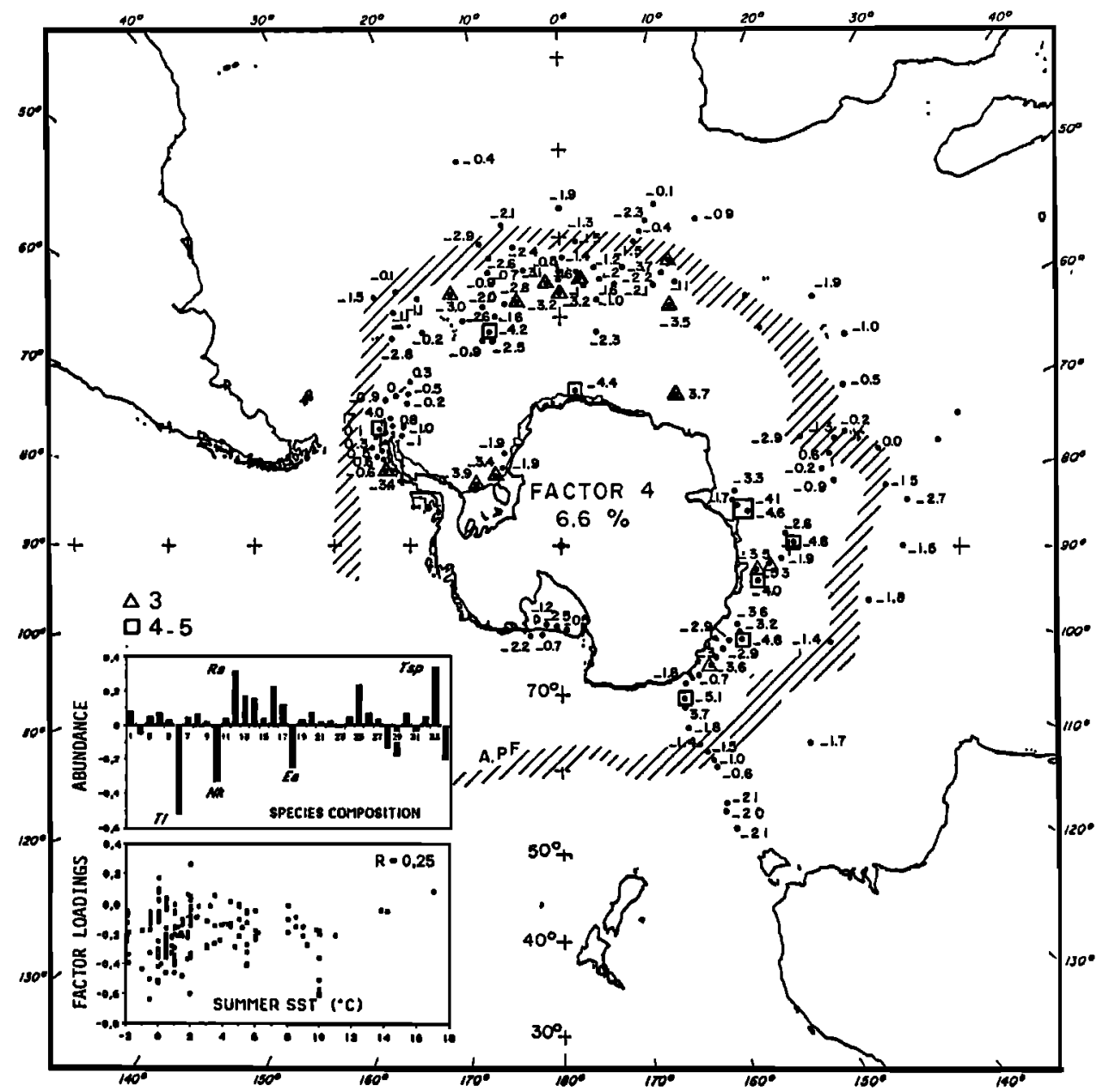

Fig. 5. "Sediment dissolution" assemblage in surface sediments of the southern ocean (factor 4 loading boundaries $\mathrm{x} 10$ ). Histogram illustrates species composition of this assemblage from Table 4. X-Y graph illustrates generalized distribution of this assemblage with respect to Summer SST from Gordon and Molinelli [1982].

abrupt low $\delta^{18} \mathrm{O}$ and $\delta^{13} \mathrm{C}$ events in core MD 84527, without equivalent changes in other isotopic records from lower latitudes. These spikes probably mark events of large meltwater input [Labeyrie et al., 1986]. Isotope stages 6,4 , and 2 are reasonably well recorded in both cores by low $\delta^{13} \mathrm{C}$ values [Labeyrie and Duplessy, 1985].

Other distortions are also introduced by large changes in sedimentation rate, a common property of the sediments of the Southern Ocean. Depending on the position of the polar front relative to the cores, fluxes of silica and sedimentation rates, vary by more than one order of magnitude [Labracherie et al 1987, Bareille 1990, Bareille et al., 1992].

\section{The SST records}

Interpretation of the $\delta^{18} O$ of $N$. pachydermas.

The $\delta^{18} \mathrm{O}$ of $N$. pachyderma $s$. may be interpreted in terms of temperature if the water $\delta^{18} \mathrm{O}$ is known [Labeyrie et al., 1986; Duplessy et al., 1991]. Extracting sea surface salinity from the Levitus [1982] atlas gives a mean salinity of $\approx+$ $33.8 \%$ for both locations, i.e., a mean water $\delta^{18} \mathrm{O} \approx-0.3 \%$ versus. SMOW, if we take into account the salinity/water $\delta^{18} \mathrm{O}$ relationship of GEOSECS [Östlund et al., 1987]. The relation 


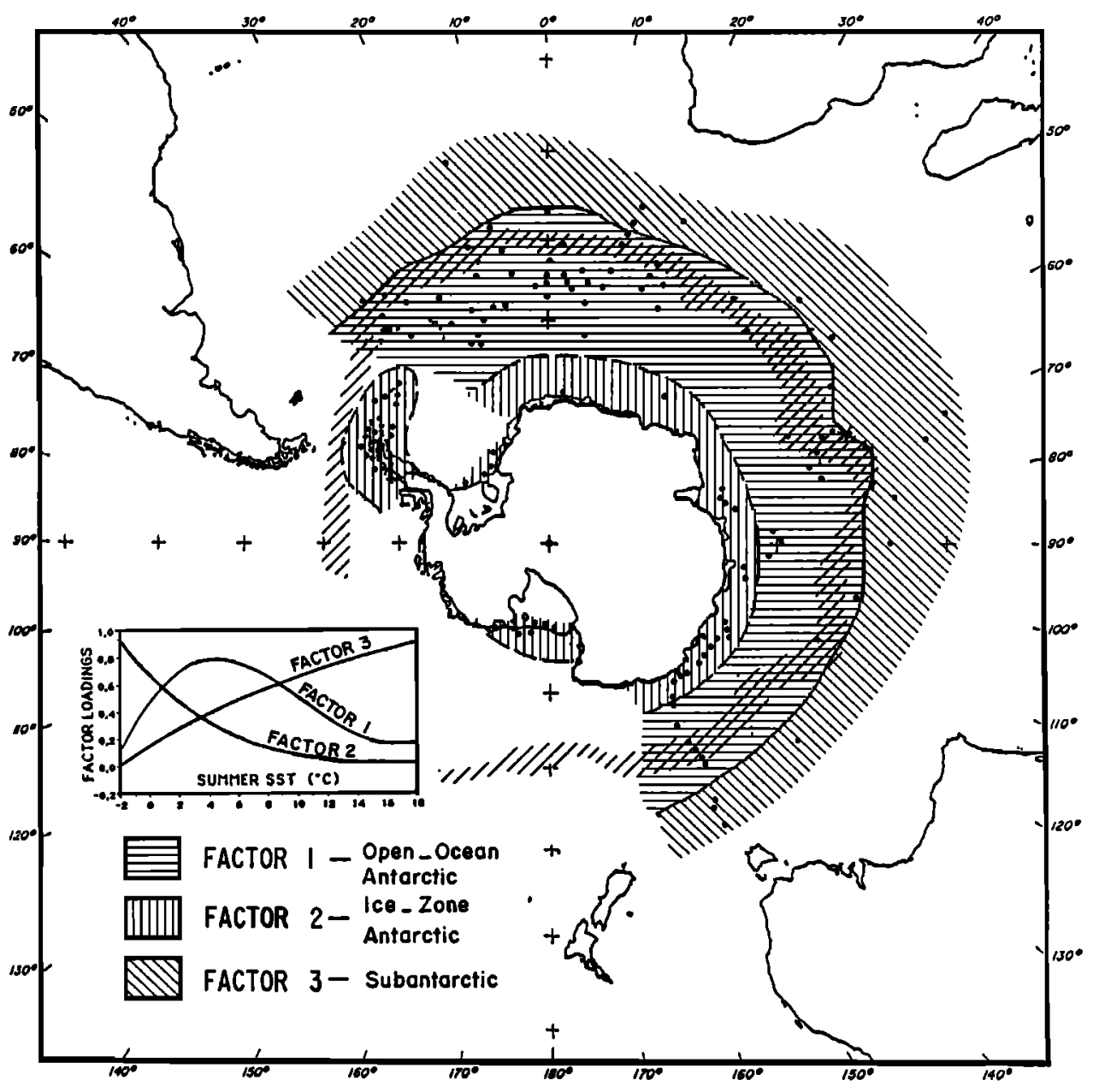

Fig. 6. Areal distribution of the three dominant diatom species assemblages defined by the varimax factor scores. X-Y graph illustrates generalized distribution of these factors with respect to Summer SST from Gordon and Molinelli [1982].

TABLE 5. Correlation Matrix

\begin{tabular}{lcccccccccc}
\hline & \multicolumn{1}{c}{ Summer Winter Autumn } & Spring Summer & \multicolumn{4}{c}{ Factor } \\
\cline { 4 - 10 } & SST & SST & SST & SST & SSS & Sea ice & 1 & 2 & 3 & 4 \\
\hline Summer SST & 1.000 & 0.977 & 0.965 & 0.966 & 0.662 & -0.680 & 0.164 & -0.820 & 0.906 & -0.056 \\
Winter SST & 1.000 & 0.959 & 0.962 & 0.685 & -0.631 & 0,121 & -0.816 & 0.886 & -0.055 \\
Autumn SST & & 1.000 & 0.943 & 0.657 & -0.673 & 0.175 & -0.805 & 0.871 & -0.036 \\
Spring SST & & & 1.000 & 0.729 & -0.572 & 0.033 & -0.754 & 0.867 & -0.038 \\
Summer SSS & & & & 1.000 & -0.218 & -0.251 & -0.421 & 0.487 & -0.019 \\
Sea ice & & & & & 1.000 & -0.751 & 0.870 & -0.672 & 0.010 \\
Factor 1 & & & & & & 1.000 & -0.565 & 0.161 & -0.038 \\
Factor 2 & & & & & & & 1.000 & -0.774 & 0.196 \\
Factor 3 & & & & & & & & 1.000 & -0.007 \\
Factor 4 & & & & & & & & & 1.000 \\
\hline
\end{tabular}

Correlation coefficients between pairs of oceanographic parameters, factors, and between oceanographic parameters and factors; SST: sea surface temperature; SSS: sea surface salinity. 
TABLE 6. Characteristics of Transfer Function DTF 166/34/4

\begin{tabular}{|c|c|c|c|c|}
\hline & Summer & Autumn SST & Winter SST & Spring SST \\
\hline MCC & 0.966 & 0.931 & 0.958 & 0.951 \\
\hline SEE & $\pm 1.0^{\circ} \mathrm{C}$ & $\pm 1.5^{\circ} \mathrm{C}$ & $\pm 1.1^{\circ} \mathrm{C}$ & $\pm 1.2^{\circ} \mathrm{C}$ \\
\hline Range & $18.9^{\circ} \mathrm{C}$ & $19,7^{\circ} \mathrm{C}$ & $14^{\circ} \mathrm{C}$ & $19.2^{\circ} \mathrm{C}$ \\
\hline Subantarctic & $-27,29$ & $-48,15$ & $-24,33$ & $-26,19$ \\
\hline Open-ocean & $-19,65$ & $-21,01$ & $-13,20$ & $-12,49$ \\
\hline Ice-zone & $-63,59$ & $-75,28$ & $-49,80$ & $-56,98$ \\
\hline Dissolution & 6,77 & 18,24 & 2,76 & 5,29 \\
\hline Subantarctic/open-ocean & $-3,49$ & $-18,19$ & $-1,12$ & $-7,22$ \\
\hline Subantarctic/ice-zone & $-2,15$ & $-8,15$ & 0,68 & $-0,08$ \\
\hline Subantarctic/dissolution & 27,30 & 24,40 & 18,65 & 18,43 \\
\hline Open-ocean/ice-zone & 16,34 & 26,24 & 16,73 & 12,18 \\
\hline Open-ocean/dissolution & 34,21 & 54,75 & 22,36 & 29,61 \\
\hline Ice-zone/dissolution & $-8,82$ & $-2,75$ & $-2,95$ & 1,25 \\
\hline Subantarctic, squared & 11,91 & 22,84 & 14,23 & 15,72 \\
\hline Open-ocean, squared & $-1,49$ & $-5,12$ & $-3,56$ & $-5,24$ \\
\hline Ice-zone, squared & 31,92 & 35,89 & 25,01 & 30,37 \\
\hline Dissolution, squared & $-0,16$ & 4,08 & 0,22 & 0,90 \\
\hline Intercept & 29,34 & 36,72 & 21,74 & 24,68 \\
\hline
\end{tabular}

MCC: multiple-correlation coefficient; SEE: standard error of estimate.

between water temperature and the oxygen isotopic fractionation in foraminiferal carbonate [O'Neil et al., 1969; Shackleton, 1974; Duplessy et al., 1991] may be applied to the measured pachyderma $s . \delta^{18} \mathrm{O}$ value of the core tops (mean top $60 \mathrm{~cm} \delta^{18} \mathrm{O}$

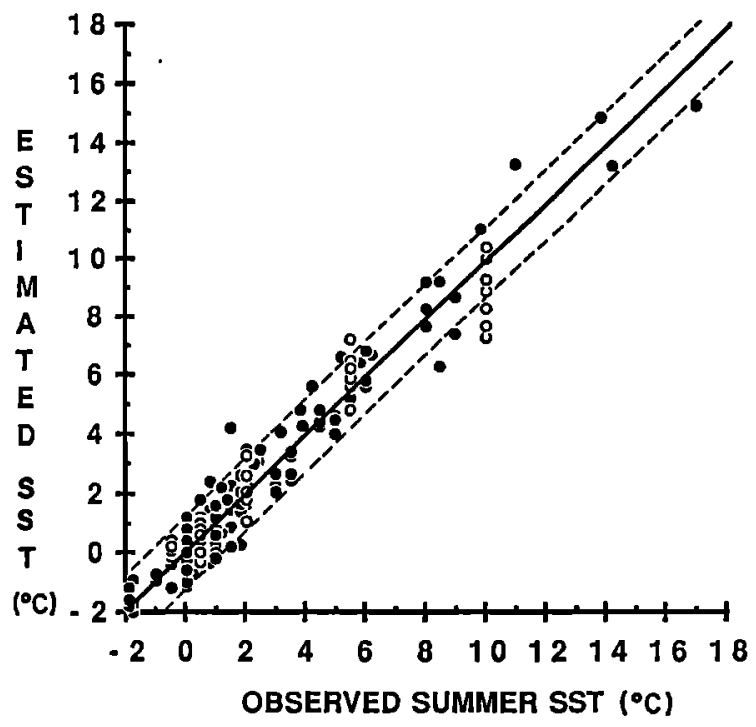

Fig. 7. Plots of estimated versus observed summer SST. Open circles correspond to the 42 artificially dissolved samples [Pichon et al., 1992]. Dashed lines define the $1 \sigma$ confidence band of the standard error of estimate: $\pm 1^{\circ} \mathrm{C}$. respectively $+1.99 \%$ and $+3.16 \%$ ). This gives $+6.3^{\circ} \mathrm{C}$ and $+2^{\circ} \mathrm{C}$ for the sea surface isotopic temperatures of cores MD 84-527 and MD 84-551, respectively. Levitus [1982] indicates, at the location of core MD 84-527, a strong temperature inversion in summer between 20 and $70 \mathrm{~m}$ below the surface, with temperatures decreasing from $+10^{\circ} \mathrm{C}$ at the surface to $+2.5^{\circ} \mathrm{C}$ at $50 \mathrm{~m}$ depth. At the location of core MD 84-551, the summer SST is homogeneous at $+2^{\circ} \mathrm{C}$ over the upper $50 \mathrm{~m}$. The isotopic results compare very well with the observed mean summer

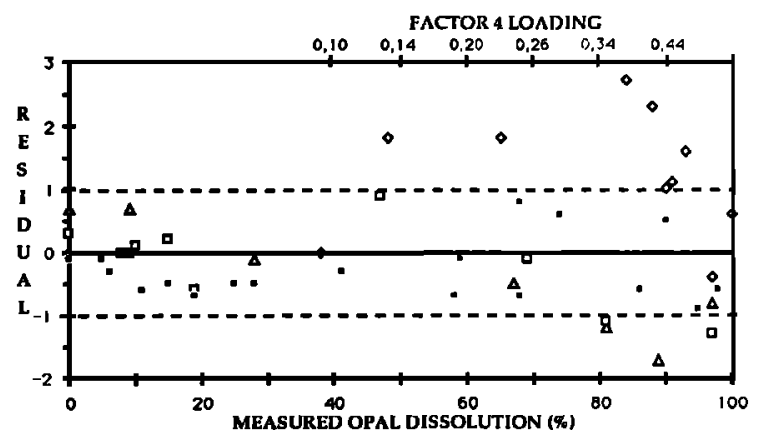

Fig. 8. Plots of residual temperatures for the 42 artificially dissolved samples versus the observed opal dissolution during the experiments [Pichon et al., 1992]. Diamonds correspond to the Subantarctic samples; others correspond to different temperature zones of southern ocean. Dashed lines define the $1 \sigma$ confidence band of the standard error of estimate: \pm $1^{\circ} \mathrm{C}$. 
TABLE 7. Residual Temperature and Calculated Opal Dissolution Percentage of 23 Holocene Surface Samples Not Used to Build the Transfer

Function DTF 166/34/4 Because of Their Poor Preservation Aspect

\begin{tabular}{lccccc}
\hline Core Top & $\begin{array}{c}\text { Summer SST } \\
\text { Measured }\end{array}$ & $\begin{array}{c}\text { Summer SST } \\
\text { Estimated }\end{array}$ & Residuals & $\begin{array}{c}\text { Factor } 4 \\
\text { Loading }\end{array}$ & $\begin{array}{c}\text { Silica Loss } \\
\text { Estimated (\%) }\end{array}$ \\
\hline 1578-8 & 0 & 1,3 & $-1,3$ & $-0,32$ & 78 \\
1678-106 & 3 & 2,6 & 0,4 & $-0,16$ & 52 \\
1678-112 & 6,5 & 5,4 & 1,1 & $-0,30$ & 75 \\
V22-102 & 3 & 2,4 & 0,6 & $-0,01$ & 18 \\
V22-104 & 4 & 3,3 & 0,7 & $-0,26$ & 69 \\
V29-87 & 4 & 3,1 & 0,9 & $-0,30$ & 75 \\
RC11-73 & 5 & 5,1 & $-0,1$ & $-0,35$ & 81 \\
RC11-79 & 5 & 5 & 0 & $-0,45$ & 91 \\
RC11-92 & 3 & 3,9 & $-0,9$ & $-0,03$ & 23 \\
RC12-289 & 6 & 5,1 & 0,9 & $-0,44$ & 90 \\
RC15-88 & 2 & 1,8 & 0,2 & $-0,29$ & 73 \\
MD80-301 & 4 & 4,5 & $-0,5$ & $-0,23$ & 64 \\
MD82-417 & 6,5 & 6 & 0,5 & $-0,02$ & 21 \\
MD82-418 & 6 & 6,1 & $-0,1$ & $-0,18$ & 56 \\
MD82-421 & 4,5 & 5,1 & $-0,6$ & $-0,16$ & 52 \\
MD82-423 & 2 & 3 & -1 & $-0,20$ & 59 \\
MD82-428 & 2 & 2,6 & $-0,6$ & $-0,22$ & 63 \\
MD82-432 & 1 & 1,1 & $-0,1$ & $-0,23$ & 64 \\
MD82-433 & 0,5 & 1,1 & $-0,6$ & $-0,27$ & 71 \\
MD82-439 & $-0,3$ & 1,2 & $-1,5$ & $-0,27$ & 71 \\
MD82-440 & 0,2 & $-0,2$ & 0,4 & $-0,48$ & 93 \\
MD82-443 & 1 & 1,7 & $-0,7$ & $-0,04$ & 26 \\
MD82-445 & 1 & 1,3 & $-0,3$ & $-0,20$ & 59 \\
\hline
\end{tabular}

SST values for the upper $30 \mathrm{~m}$. Curiously, in these cores, $N$. pachyderma $s$. does not show the systematic difference of $\approx-2.5^{\circ} \mathrm{C}$ between observed and isotopic temperatures that is apparent in the North Atlantic Ocean [Duplessy et al., 1991]. This could derive from differences in the growth season.

The sedimentation rate in core MD 84-527 is low during the Last Glacial Maximum (less than $2 \mathrm{~cm} / \mathrm{kyr}$ [Labracherie et al., 1989; Bard et al., 1989]) and N. pachyderma s. shells are rare. The $\delta^{18} \mathrm{O}$ values for LGM, lighter (by approximately $0.6 \%$ ) than in the

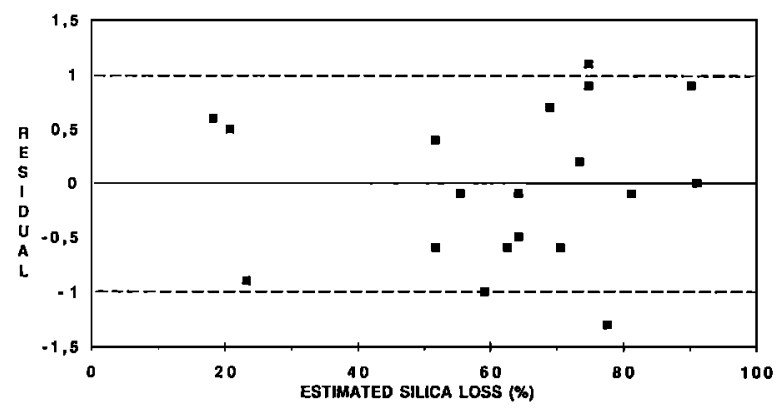

Fig. 9. Plots of residual temperatures for the 23 Holocene surface samples not used in development of the transfer function D166/34/4 (from Table 7).
LGM levels of near-by core MD 73-025 [Duplessy et al., 1980] are therefore probable not representative. A value of $+4.1 \%$ (as in core MD 73-

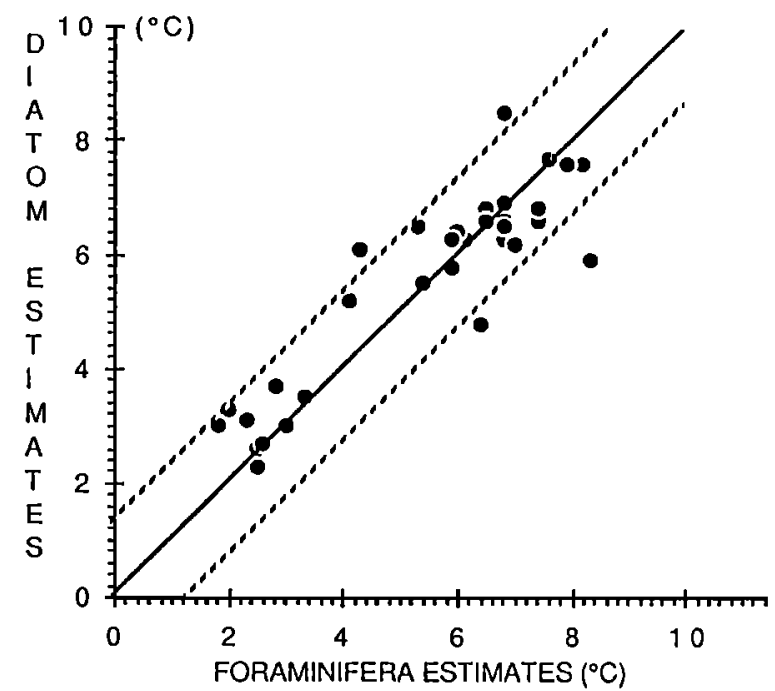

Fig. 10. Comparison between the foraminiferal and diatom SST estimates in the Holocene section of Subantarctic core MD 84-527. 


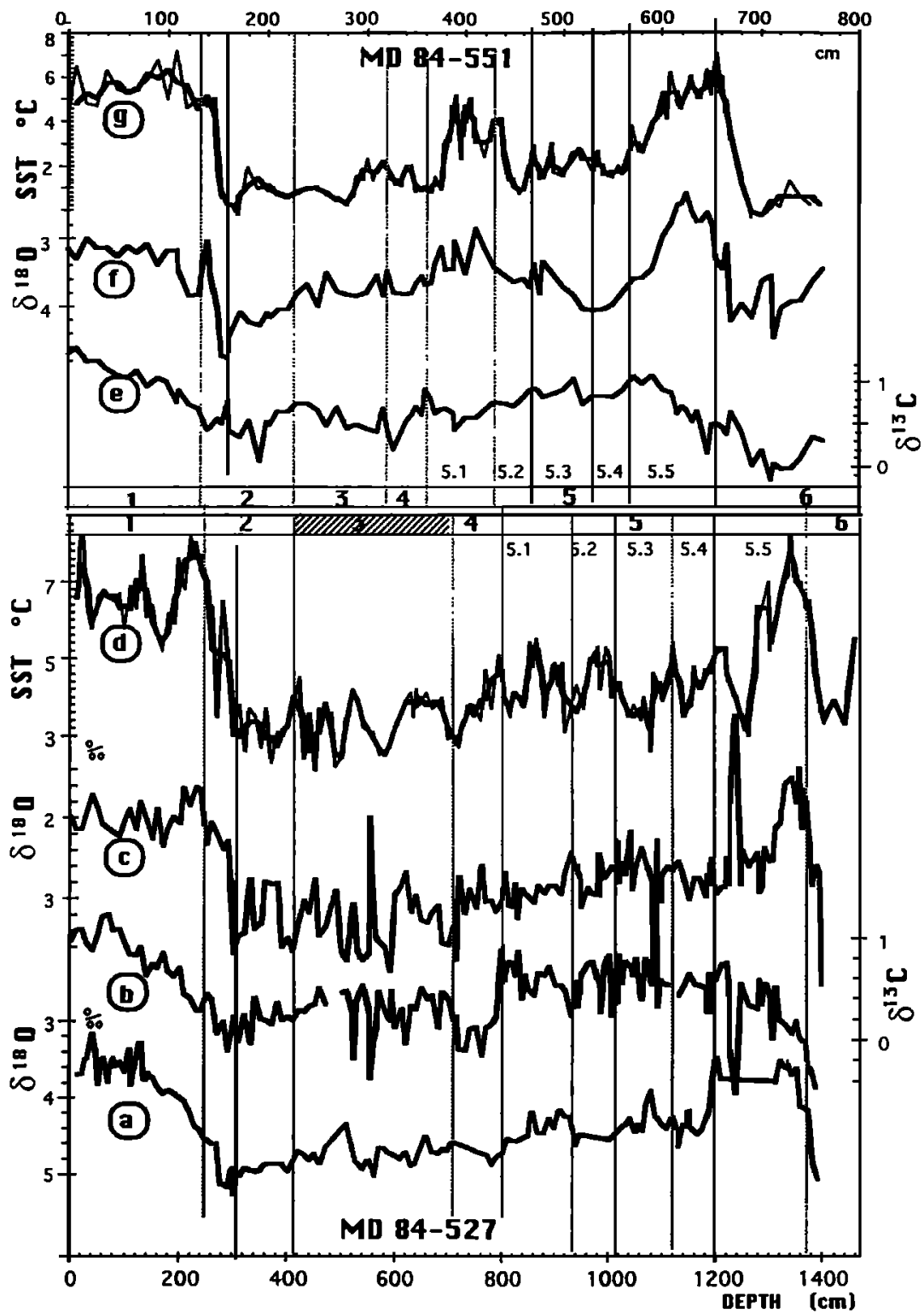

Fig. 11. Distribution with depth and Emiliani's stages in cores MD 84-527 (44. $\mathrm{S}, 51^{\circ} \mathrm{E} ; 3,262 \mathrm{~m}$ depth) and MD 84-551 $\left(55^{\circ} \mathrm{S}, 73^{\circ} \mathrm{E} ; 1,504 \mathrm{~m}\right.$ depth) of (a) $\delta^{18} \mathrm{O}$ of the benthic foraminifera Cibicides wuellerstorfii in core MD 84-527; (b) $\delta^{13} \mathrm{C}$ of the planktonic foraminifera $N$. pachyderma $s$. in core MD 84-527; (c) $\delta^{18} \mathrm{O}$ of $N$. pachyderma $s$. in core MD 84-527, (d) diatom summer SST in core MD 84-527; (e) $\delta^{13} \mathrm{C}$ of the planktonic foraminifera $N$. pachyderma s.. in core MD 84-551, (f) $\delta^{18} \mathrm{O}$ of $N$. pacyderma $s$. in core MD 84-551; and (g) diatom summer SST in core MD 84-551.

025 ) corresponds if the mean ocean water $\delta^{18} \mathrm{O}$ is increased by $1.2 \%$ [Labeyrie et al., 1987; Shackleton, 1987] to a water temperature of $+3^{\circ} \mathrm{C}$. For core MD 84-551 the mean LGM $\delta^{18} \mathrm{O}$ value of $+4.6 \%$ corresponds to a SST value of $+1^{\circ} \mathrm{C}$ if the salinity gradients have not changed since the LGM.

The interpretation of $N$. pachyderma $s . \delta^{18} \mathrm{O}$ in terms of sea surface temperature may not be extended to other periods, because of the lack of constraints on the changes of surface water $\delta^{18} \mathrm{O}$.

The diatom transfer function. Tables $8 \mathrm{a}$ and $8 \mathrm{~b}$, and Figure 11 present the results of the application of DTF 166/34/4 to cores MD 84-527 and MD 84-551. Communalities stay high $(>0.8)$ throughout both records. The large changes in summer sea surface temperature $\left(>5^{\circ} \mathrm{C}\right)$ estimated by the DTF are mostly 
TABLE 8a. Changes in the Benthic and Planktonic Foraminifera $\partial 180$ and $\partial 13 \mathrm{C}$, and Summer SST Estimated by the Transfer Function DTF 166/34/4 in Core MD 84-527

\begin{tabular}{|c|c|c|c|c|c|c|c|c|c|c|c|c|c|}
\hline \multirow{2}{*}{$\begin{array}{c}\text { Depth, } \\
\text { cm }\end{array}$} & \multirow{2}{*}{$\begin{array}{c}\text { Age, } \\
\text { ka }\end{array}$} & \multicolumn{2}{|c|}{$\begin{array}{c}\text { Benthic } \\
\text { Foraminifera } \\
\partial 180, \partial 13 \mathrm{C} \text {, }\end{array}$} & $\frac{\text { pachyo }}{\partial 180}$ & $\begin{array}{l}\text { N. } \\
\text { lerma } \\
13 \mathrm{C}\end{array}$ & SSST & Depth, & Age, & $\begin{array}{l}\text { Bent } \\
\text { Foram } \\
\partial 180,\end{array}$ & $\begin{array}{l}\text { hic } \\
\text { inifera } \\
\partial 13 \mathrm{C},\end{array}$ & $\frac{\text { pachy }}{\partial 180}$ & $\begin{array}{l}N . \\
\text { lerma s } \\
13 \mathrm{C},\end{array}$ & SSST \\
\hline & & $\%$ & $\%$ & $\%$ & $\% 0$ & ${ }^{\circ} \mathrm{C}$ & $\mathrm{cm}$ & ka & $\%$ & $\% o$ & $\%$ & $\%$ & ${ }^{\circ} \mathrm{C}$ \\
\hline 0 & 1,00 & - & & 1,98 & $0, \overline{98}$ & 6,8 & 865 & 71,71 & - & - & - & - & 5,0 \\
\hline 5 & 1,25 & 3,73 & 0,28 & - & - & - & 870 & 71,97 & 4,46 & $-0,24$ & 2,84 & 0,67 & - \\
\hline 10 & 1,50 & - & - & 2,14 & 1,07 & 6,6 & 875 & 72,24 & - & - & - & - & 4,5 \\
\hline 13 & 1,65 & 3,69 & 0,51 & - & - & - & 880 & 72,50 & 4,45 & 0,02 & 2,94 & 0,64 & 4,5 \\
\hline 20 & 2,00 & - & - & 2,14 & 1,10 & 8,5 & 890 & 74,70 & 4,27 & 0,14 & 2,84 & 0,72 & \\
\hline 23 & 2,15 & 3,67 & 0,19 & - & - & - & 895 & 75,80 & - & - & - & - & 4,3 \\
\hline 30 & 2,50 & 3,48 & 0,45 & 1,96 & 0,95 & 6,8 & 900 & 76,90 & 4,39 & - & 2,85 & 0,54 & 4,7 \\
\hline 40 & 3,00 & 3,17 & 0,13 & 1,71 & 0,89 & 6,5 & 905 & 78,00 & - & - & - & - & 4,6 \\
\hline 50 & 3,50 & 3,52 & 0,23 & 1,89 & 1,06 & 6,2 & 910 & 79,10 & 4,16 & 0,10 & 2,95 & 0,54 & \\
\hline 53 & 3,65 & 3,81 & 0,42 & - & - & - & 915 & 80,20 & - & - & - & - & 4,3 \\
\hline 60 & 4,00 & 3,48 & 0,13 & 2,09 & 1,22 & 6,6 & 920 & 81,30 & 4,25 & 0,15 & 2,69 & 0,48 & 3,9 \\
\hline 70 & 4,50 & 3,79 & 0,37 & 2,15 & 1,23 & 6,8 & 928 & 83,06 & 4,25 & $-0,10$ & - & - & - \\
\hline 73 & 4,65 & 3,63 & 0,31 & & - & - & 930 & 83,50 & - & - & 2,44 & 0,25 & - \\
\hline 80 & 5,00 & 3,48 & 0,14 & 2,19 & 1,08 & 6,5 & 938 & 84,58 & - & - & 2,60 & 0,5 & - \\
\hline 83 & 5,15 & 3,59 & 0,26 & - & - & - & 940 & 84,85 & 4,62 & 0,05 & 2,64 & 0,45 & 3,8 \\
\hline 90 & 5,50 & 3,53 & 0,07 & 2,23 & 1,09 & 6,4 & 946 & 85,66 & - & - & 2,75 & 0,47 & - \\
\hline 100 & 6,00 & 3,66 & 0,00 & 2,01 & 0,94 & 6,3 & 950 & 86,20 & 4,48 & 0,28 & 3,10 & 0,64 & - \\
\hline 110 & 6,25 & 3,37 & $-0,24$ & 1,90 & 0,85 & 6,6 & 955 & 86,85 & - & - & - & - & 3,9 \\
\hline 113 & 6,33 & 3,83 & $-0,16$ & - & - & - & 960 & 87,50 & - & - & 2,88 & 0,75 & 4,5 \\
\hline 120 & 6,50 & - & - & 2,14 & 0,84 & 6,7 & 965 & 88,15 & - & - & - & - & 4,8 \\
\hline 130 & 6,75 & 3,29 & $-0,18$ & 1,80 & 0,93 & 6,9 & 970 & 88,80 & - & - & 2,95 & 0,78 & \\
\hline 138 & 6,95 & 3,77 & $-0,19$ & • & - & - & 975 & 89,45 & - & - & - & - & 4,9 \\
\hline 140 & 7,00 & - & - & 2,02 & 0,64 & 6,6 & 978 & 89,84 & - & - & 2,97 & 0,61 & \\
\hline 143 & 7,08 & 3,67 & $-0,18$ & - & - & - & 980 & 90,10 & - & - & 2,46 & 0,59 & 4,9 \\
\hline 150 & 7,25 & 3,73 & $-0,11$ & 2,26 & 0,75 & 6,1 & 985 & 90,75 & - & - & 2,74 & 0,42 & 5,0 \\
\hline 160 & 7,50 & 3,85 & 0,00 & 1,89 & 0,71 & 5,6 & 990 & 91,40 & - & - & 2,75 & 0,71 & - \\
\hline 170 & 7,75 & 3,94 & $-0,15$ & 2,36 & 0,85 & 5,5 & 995 & 92,05 & - & - & - & - & 4,8 \\
\hline 180 & 8,00 & 3,90 & $-0,51$ & 2,14 & 0,69 & 5,9 & 1000 & 92,70 & 4,56 & $-0,02$ & 2,68 & 0,83 & 4,6 \\
\hline 190 & 8,33 & - & - & 1,98 & 0,63 & 6,3 & 1003 & 92,89 & 4,24 & 0,17 & - & - & \\
\hline 200 & 8,67 & - & - & 2,07 & 0,71 & 7,0 & 1005 & 93,02 & - & - & 2,62 & 0,24 & 4,6 \\
\hline 210 & 9,00 & 4,06 & $-0,12$ & 1,64 & 0,45 & 7,4 & 1010 & 93,34 & - & - & 2,66 & 0,69 & - \\
\hline 220 & 9,33 & 4,20 & 0,01 & 1,85 & 0,42 & 7,9 & 1013 & 93,53 & 4,26 & - & - & - & - \\
\hline 230 & 9,68 & 4,38 & $-0,12$ & 1,63 & 0,29 & 7,7 & 1015 & 93,66 & - & - & 2,31 & 0,38 & 4,3 \\
\hline 240 & 10,05 & 4,43 & $-0,40$ & 1,69 & 0,29 & 7,7 & 1020 & 93,97 & - & - & 2,79 & 0,83 & 4,1 \\
\hline 250 & 10,41 & 4,54 & $-0,31$ & 2,32 & 0,45 & 6,4 & 1023 & 94,16 & 3,75 & 0,12 & - & - & - \\
\hline 260 & 10,77 & 4,60 & $-0,22$ & 2,06 & 0,39 & 5,8 & 1025 & 94,29 & . & & 2,57 & 0,57 & 4,0 \\
\hline 270 & 11,14 & 4,61 & $-0,29$ & 2,22 & 0,08 & 5,4 & 1030 & 94,61 & 4,36 & $-0,01$ & 2,70 & 0,77 & \\
\hline 280 & 11,50 & 5,13 & $-0,38$ & 2,41 & 0,18 & 4,9 & 1037 & 95,06 & - & - & - & - & 3,8 \\
\hline 290 & 13,25 & 5,18 & $-0,35$ & 2,29 & $-0,09$ & 4,5 & 1040 & 95,25 & 4,27 & 0,07 & 2,19 & 0,72 & 3,6 \\
\hline 293 & 13,78 & 5,04 & $-0,55$ & - & - & - & 1043 & 95,44 & 4,17 & 0,06 & 2,90 & 0,63 & \\
\hline 300 & 15,00 & 4,92 & $-0,38$ & 3,54 & 0,19 & 4,1 & 1046 & 95,96 & - & - & - & - & 3,6 \\
\hline 302 & 15,83 & 5,26 & $-0,44$ & 3,68 & 0,24 & - & 1050 & 96,88 & 4,45 & 0,23 & 2,64 & 0,80 & - \\
\hline 310 & 19,17 & 4,98 & $-0,33$ & 3,48 & 0,00 & 3,1 & 1053 & 97,57 & 4,35 & 0,64 & - & - & - \\
\hline 313 & 20,42 & 5,02 & $-0,77$ & - & - & - & 1060 & 99,18 & - & - & 2,38 & 0,40 & 3,8 \\
\hline 320 & 23,33 & 4,93 & $-0,64$ & 3,43 & 0,24 & 3,2 & 1063 & 99,87 & 4,44 & 0,14 & - & - & - \\
\hline 330 & 25,53 & 4,95 & $-0,45$ & 2,78 & $-0,03$ & 3,3 & 1065 & 100,32 & - & - & - & - & 3,4 \\
\hline 340 & 26,41 & 4,97 & $-0,68$ & 3,39 & 0,41 & 3,3 & 1070 & 101,47 & 4,11 & 0,31 & 2,57 & 0,80 & \\
\hline
\end{tabular}


TABLE 8a. (continued)

\begin{tabular}{|c|c|c|c|c|c|c|c|c|c|c|c|c|c|}
\hline \multirow{2}{*}{$\begin{array}{c}\text { Depth, } \\
\text { cm }\end{array}$} & \multirow{2}{*}{$\begin{array}{c}\text { Age, } \\
\text { ka }\end{array}$} & \multirow{2}{*}{\multicolumn{2}{|c|}{$\begin{array}{c}\text { Benthic } \\
\text { Foraminifera } \\
\partial 180, \partial 13 \mathrm{C} \\
\% 0 \% \%\end{array}$}} & \multicolumn{2}{|c|}{$\begin{array}{c}N . \\
\text { pachydermas } \\
\text { J18O, } 213 \mathrm{C}\end{array}$} & \multirow{2}{*}{$\begin{array}{l}\text { SSST } \\
{ }^{\circ} \mathrm{C}\end{array}$} & \multirow{2}{*}{$\begin{array}{c}\text { Depth } \\
\text { cm }\end{array}$} & \multirow{2}{*}{$\begin{array}{c}\text { Age, } \\
\text { ka } \\
\end{array}$} & \multirow{2}{*}{\multicolumn{2}{|c|}{$\begin{array}{c}\text { Benthic } \\
\text { Foraminifera } \\
\partial 18 \mathrm{O}, \partial 13 \mathrm{C}, \\
\% \circ \quad \% 0\end{array}$}} & \multirow{2}{*}{\multicolumn{3}{|c|}{ 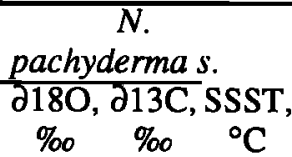 }} \\
\hline & & & & $\%$ & $\%$ & & & & & & & & \\
\hline 350 & 27,29 & 4,94 & $-0,54$ & 3,31 & 0,21 & 3,3 & 107. & 102,62 & - & - & - & - & 3,4 \\
\hline 360 & 28,07 & 4,88 & $-0,80$ & 2,80 & 0,20 & 3,0 & 108 & 103,77 & 3,91 & 0,53 & 2,79 & 0,55 & 3,6 \\
\hline 370 & 28,44 & 4,86 & $-0,47$ & 2,83 & 0,17 & 2,9 & 108 & 104,31 & & - & - & - & 3,7 \\
\hline 380 & 28,81 & 4,86 & $-0,47$ & 2,82 & 0,37 & 2,9 & 109 & 104,69 & 4,25 & $-0,17$ & 2,29 & 0,73 & \\
\hline 390 & 29,17 & 4,87 & $-0,09$ & 3,60 & 0,19 & 2,9 & 1092 & 104,85 & - & - & 2,98 & 0,34 & - \\
\hline 400 & 29,54 & 4,96 & $-0,86$ & 3,50 & 0,24 & 3,7 & 109 & 105,15 & - & - & 3,04 & 0,59 & 4,0 \\
\hline 410 & 29,90 & - & - & 3,67 & 0,19 & 3,6 & $110 x$ & 105,46 & 4,35 & 0,11 & 2,72 & 0,57 & 4,6 \\
\hline 420 & 30,27 & 4,70 & $-0,73$ & 3,29 & 0,29 & 3,7 & 1110 & 106,23 & 4,41 & 0,15 & 2,61 & 0,54 & - \\
\hline 430 & 30,63 & 4,74 & $-0,60$ & 3,04 & 0,29 & 3,3 & 1115 & 106,62 & - & - & - & - & 4,5 \\
\hline 440 & 31,00 & 4,82 & $-0,48$ & 3,19 & 0,33 & 3,0 & 1120 & 107,00 & 4,26 & 0,16 & 2,67 & - & 4,5 \\
\hline 450 & 31,98 & 4,73 & $-0,44$ & 2,77 & 0,36 & 2,9 & 1128 & 107,53 & 4,41 & $-0,05$ & - & - & - \\
\hline 460 & 32,97 & 4,85 & $-0,34$ & 3,46 & 0,52 & 3,4 & 1130 & 107,67 & 4,64 & - & 2,56 & 0,45 & - \\
\hline 470 & 33,95 & 4,65 & $-0,47$ & 3,35 & 0,35 & 3,3 & 113 & 108,00 & - & - & - & - & 4,2 \\
\hline 480 & 34,93 & - & - & - & - & 3,2 & 1140 & 108,33 & 4,35 & $-0,44$ & 2,80 & 0,56 & 4,0 \\
\hline 490 & 35,92 & - & - & 2,91 & - & 2,7 & 114 & 108,67 & 4,37 & 0,51 & - & - & \\
\hline 500 & 36,90 & - & - & 3,64 & 0,47 & 2,8 & 1149 & 108,93 & 4,17 & 0,12 & - & - & - \\
\hline 510 & 37,89 & 4,40 & $-0,29$ & 3,76 & 0,50 & 3,3 & 1150 & 109,00 & 4,38 & - & 3,01 & 0,66 & - \\
\hline 520 & 38,87 & - & - & 3,21 & 0,28 & 3,8 & 115 & 109,27 & - & - & & - & 3,9 \\
\hline 522 & 39,07 & 4,41 & 0,42 & 3,08 & $-0,17$ & - & 1160 & 109,67 & - & - & 2,75 & 0,55 & 4,2 \\
\hline 527 & 39,56 & - & - & 3,49 & 0,38 & - & 116 & 109,93 & 4,48 & 0,06 & - & - & - \\
\hline 530 & 39,85 & 4,85 & $-0,18$ & 3,64 & 0,40 & 3,9 & 1167 & 110,13 & - & - & - & - & 4,4 \\
\hline 540 & 40,84 & 4,94 & $-0,59$ & 3,76 & 0,54 & 3,6 & 1170 & 110,33 & - & - & 2,75 & 0,54 & - \\
\hline 550 & 41,82 & 4,82 & $-0,58$ & 3,67 & 0,30 & 3,1 & 1175 & 110,67 & 4,40 & 0,53 & - & - & 4,4 \\
\hline 560 & 42,80 & 5,02 & $-0,53$ & 3,07 & 0,00 & 2,8 & 1180 & 111,00 & - & - & 2,98 & 0,52 & 4,5 \\
\hline 563 & 43,10 & - & 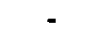 & 3,46 & 0,02 & - & 1182 & 111,50 & - & - & 2,73 & 0,28 & - \\
\hline 570 & 43,82 & 4,65 & $-0,65$ & 3,53 & 0,47 & 2,7 & 1187 & 112,75 & 4,15 & 0,02 & 2,92 & 0,69 & - \\
\hline 580 & 44,83 & 4,66 & $-0,86$ & 3,62 & 0,28 & 2,6 & 1188 & & - & - & 2,73 & 0,34 & - \\
\hline 590 & 45,85 & 4,72 & $-0,54$ & 3,89 & 0,19 & 2,8 & 1190 & & - & - & 2,53 & 0,56 & - \\
\hline 600 & 46,87 & - & - & 2,97 & 0,14 & 3,3 & 1194 & 114,50 & - & - & - & - & 4,9 \\
\hline 610 & 47,89 & 4,80 & $-0,53$ & 2,85 & 0,30 & - & 1200 & 116,00 & 3,48 & $-0,12$ & 2,96 & 0,60 & 5,2 \\
\hline 620 & 48,91 & 4,71 & $-0,90$ & 2,69 & $-0,02$ & 3,6 & 1208 & 117,02 & 3,74 & 0,13 & - & - & - \\
\hline 630 & 49,93 & 4,89 & $-0,61$ & 3,17 & 0,35 & 3,9 & 1210 & 117,27 & - & - & 2,86 & 0,75 & \\
\hline 635 & 50,44 & - & - & - & - & 4,0 & 1216 & 118,04 & 3,80 & $-0,38$ & 2,87 & 0,72 & 5,0 \\
\hline 639 & 50,84 & 4,84 & $-0,43$ & - & - & - & 1220 & 118,55 & - & - & 2,51 & 0,76 & 4,7 \\
\hline 640 & 50,94 & - & - & 2,97 & 0,31 & 3,9 & 1224 & - & - & $-0,72$ & 2,84 & 0,45 & - \\
\hline 645 & 51,45 & - & - & - & - & 3,9 & 12 & - & - & - & 3,23 & 0,75 & - \\
\hline 650 & & - & - & 3,28 & 0,51 & - & 1240 & - & - & - & - & - & 3,7 \\
\hline 660 & 52,98 & 4,51 & $-0,52$ & 3,31 & 0,41 & 3,9 & 1246 & - & - & - & 2,83 & 0,55 & - \\
\hline 663 & 53,29 & 4,48 & 0,07 & - & - & - & 1250 & - & - & - & 2,42 & 0,51 & - \\
\hline 670 & 54,00 & 4,71 & $-0,55$ & 3,18 & 0,45 & 3,9 & 1255 & - & - & - & - & - & 3,4 \\
\hline 680 & 54,63 & 4,73 & $-0,38$ & 3,10 & 0,13 & 3,8 & 1260 & - & - & - & 2,62 & 0,34 & 3,7 \\
\hline 690 & 55,26 & 4,66 & $-0,72$ & 3,55 & 0,48 & 3,6 & 1276 & - & - & - & 2,50 & 0,34 & 4,9 \\
\hline 700 & 55,90 & 4,70 & $-0,78$ & 3,58 & 0,41 & 3,2 & 1280 & - & - & - & 2,92 & 0,58 & 5,7 \\
\hline 708 & 56,40 & 4,58 & $-0,61$ & - & - & - & 1286 & - & - & & 2,85 & 0,36 & - \\
\hline 710 & 56,53 & - & - & 3,31 & 0,17 & - & 1290 & - & - & - & 2,38 & 0,55 & - \\
\hline 712 & 56,65 & - & & 3,66 & 0,04 & - & 1297 & - & - & - & - & - & 6,2 \\
\hline 715 & 56,84 & - & - & 3,75 & 0,23 & 2,9 & 1300 & - & - & - & 2,56 & 0,44 & 6,0 \\
\hline 720 & 57,16 & - & - & 2,74 & $-0,09$ & 2,9 & 1305 & - & - & - & 2,58 & 0,05 & 5,9 \\
\hline
\end{tabular}


TABLE 8a. (continued)

\begin{tabular}{|c|c|c|c|c|c|c|c|c|c|c|c|c|c|}
\hline \multirow{2}{*}{$\begin{array}{c}\text { Depth, } \\
\mathrm{cm}\end{array}$} & \multirow{2}{*}{$\begin{array}{c}\text { Age, } \\
\text { ka }\end{array}$} & \multirow{2}{*}{\multicolumn{2}{|c|}{$\begin{array}{c}\text { Benthic } \\
\text { Foraminifera } \\
\partial 180, \partial 13 \mathrm{C}, \\
\% 0 \quad \% 0\end{array}$}} & \multicolumn{2}{|c|}{$\begin{array}{c}N . \\
\text { pachyderma } \\
\text { D18O, ग13C, }\end{array}$} & \multirow[t]{2}{*}{$\begin{array}{l}\text { SSST, } \\
{ }^{\circ} \mathrm{C}\end{array}$} & \multirow{2}{*}{$\begin{array}{c}\text { Depth, } \\
\text { cm }\end{array}$} & \multirow{2}{*}{$\begin{array}{c}\text { Age, } \\
\text { ka }\end{array}$} & \multirow{2}{*}{\multicolumn{2}{|c|}{$\begin{array}{c}\text { Benthic } \\
\text { Foraminifera } \\
\partial 180, \partial 13 \mathrm{C}, \\
\% \circ \quad \% o\end{array}$}} & \multicolumn{3}{|c|}{$\begin{array}{c}N . \\
\text { pachyderma s. } \\
\text { J18O, J13C, SSST }\end{array}$} \\
\hline & & & & $\%$ & $\%$ & & & & & & $\%$ & $\%$ & ${ }^{\circ} \mathrm{C}$ \\
\hline 725 & 57,47 & - & 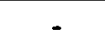 & - & - & 3,2 & 1310 & 119,35 & 3,80 & - & 2,15 & 0,51 & - \\
\hline 730 & 57,79 & - & - & 3,19 & $-0,10$ & & 1315 & 119,94 & & - & & & 5,9 \\
\hline 735 & 58,11 & - & - & - & - & 3,6 & 1318 & 120,29 & 3,52 & 0,27 & 2,06 & 0,2 & - \\
\hline 740 & 58,42 & - & - & 2,90 & 0,11 & 3,7 & 1320 & 120,53 & - & - & - & - & 6,9 \\
\hline 745 & 58,74 & - & - & - & - & 3,9 & 1330 & 122,00 & 3,62 & $-0,12$ & 1,59 & 0,15 & - \\
\hline 750 & 59,05 & 4,69 & $-0,72$ & 3,13 & 0,13 & - & 1333 & 122,50 & 3,57 & $-0,26$ & - & - & - \\
\hline 760 & 59,68 & 4,72 & $-0,61$ & 2,60 & $-0,15$ & 3,8 & 1336 & 123,00 & - & - & - & - & 7,4 \\
\hline 770 & 60,98 & 4,75 & $-0,91$ & 3,05 & 0,13 & 4,1 & 1340 & 123,67 & 3,71 & $-0,36$ & 1,52 & 0,06 & 7,6 \\
\hline 780 & 62,93 & 4,88 & $-0,28$ & 3,03 & 0,16 & 4,4 & 1346 & 124,67 & - & - & - & - & 7,5 \\
\hline 790 & 64,89 & 4,78 & $-0,52$ & 3,17 & 0,23 & - & 1350 & 125,33 & 3,62 & 0,13 & 1,82 & 0,19 & - \\
\hline 795 & & - & - & & - & 4,7 & & 5,17 & - & & 1,41 & 0,03 & 7,1 \\
\hline 800 & 66,84 & 4,73 & $-0,19$ & 3,05 & 0,89 & 4,4 & 1360 & 127,00 & 4,12 & 0,03 & 2,14 & $-0,01$ & 6,7 \\
\hline 805 & 67,82 & - & - & 2,70 & 0,58 & 4,2 & 1365 & 127,83 & - & - & 1,67 & 0,00 & 6,6 \\
\hline 810 & 68,80 & 4,53 & 0,17 & 2,90 & 0,74 & - & 1370 & 128,67 & 4,19 & $-0,45$ & 2,23 & $-0,27$ & - \\
\hline 815 & 69,06 & - & - & 3,09 & 0,77 & 3,8 & 1375 & 129,50 & - & & 2,40 & $-0,28$ & 6,2 \\
\hline 820 & 69,33 & 4,57 & $-0,03$ & 3,10 & 0,76 & 3,8 & 1380 & 130,33 & 4,83 & $-0,69$ & 2,85 & $-0,36$ & 5,5 \\
\hline 825 & 69,59 & - & - & 2,83 & 0,64 & 3,9 & 1385 & 131,17 & - & $-0,84$ & 2,62 & $-0,47$ & 4,7 \\
\hline 830 & 69,86 & 4,56 & 0,25 & 3,24 & 0,87 & - & 1390 & 132,00 & 5,08 & & 2,71 & $-0,25$ & - \\
\hline 835 & 70,12 & - & - & 2,89 & 0,56 & 3,9 & 1395 & 132,83 & - & - & 4,08 & 0,08 & 4,0 \\
\hline 840 & 70,39 & - & - & 2,89 & 0,42 & 4,1 & 1400 & 133,67 & - & - & - & - & 3,4 \\
\hline 845 & 70,65 & - & - & 2,96 & 0,64 & 4,3 & 1420 & 137,00 & - & - & - & - & 3,9 \\
\hline 850 & 70,91 & 4,49 & $-0,03$ & 2,98 & 0,50 & - & 1440 & 140,33 & - & - & - & - & 3,3 \\
\hline 855 & 71,18 & - & - & - & - & 4,8 & 1460 & 143,67 & - & - & - & - & 5,5 \\
\hline 860 & 71,44 & 4,19 & 0,21 & 3,06 & 0,44 & 5,3 & & & & & & & \\
\hline
\end{tabular}

The SST values are smoothed with a five-point Gaussian filter.

TABLE $8 \mathrm{~b}$. Changes in the Planktonic Foraminifera $\partial 180$ and $\partial 13 \mathrm{C}$, and Summer SST Estimated by the Transfer Function DTF 166/34/4 in Core MD 84-551

\begin{tabular}{|c|c|c|c|c|c|c|c|c|c|c|c|c|c|c|}
\hline & & & & & & & & & & & Age, & & & \\
\hline $\mathrm{cm}$ & $\mathrm{ka}$ & $\%$ & $\%$ & ${ }^{\circ} \mathrm{C}$ & $\mathrm{cm}$ & $\mathbf{k a}$ & $\% o$ & $\% o$ & ${ }^{\circ} \mathrm{C}$ & $\mathrm{cm}$ & $\mathrm{ka}$ & $\% o$ & $\%$ & ${ }^{\circ} \mathrm{C}$ \\
\hline 0 & 0,80 & 3,15 & 1,35 & $\overline{4,4}$ & 300 & 46,13 & 3,81 & $\overline{0,45}$ & 1,7 & 500 & 101,59 & 3,73 & $\overline{0,91}$ & 2,1 \\
\hline 10 & 1,64 & 3,31 & 1,40 & 6,5 & 306 & 46,88 & - & - & 1,8 & 510 & 104,19 & 3,85 & 1,04 & 2,2 \\
\hline 20 & 2,49 & 3,00 & 1,25 & 4,8 & 310 & 48,04 & 3,55 & 0,41 & 1,9 & 516 & 105,74 & - & - & 4 \\
\hline 30 & 3,33 & 3,15 & 1,26 & 5,5 & 316 & 50,13 & & & 1,8 & 520 & 106,65 & 4,04 & 0,74 & 2,5 \\
\hline 40 & 4,18 & 3,14 & 1,16 & 5,3 & 320 & 51,52 & 3,48 & 0,46 & 1,9 & 530 & 108,81 & 4,09 & 0,83 & 2,3 \\
\hline 50 & 5,02 & 3,27 & 1,09 & 5,6 & 326 & 53,61 & & 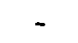 & 1,5 & 535 & 109, & & & 2,1 \\
\hline 60 & 5,86 & 3,13 & 1,06 & 5,6 & 330 & 55,00 & & 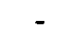 & 1,3 & 540 & 110,97 & 4,06 & 0,83 & 1,8 \\
\hline 70 & 6,71 & 3,21 & 1,14 & 5,7 & 335 & 58,00 & - & & 1,5 & 545 & 112,05 & & $x_{0}$ & 1,8 \\
\hline 80 & 7,55 & 3,09 & 0,95 & 5,7 & 340 & 61,00 & 3,83 & 0,53 & 1,6 & 550 & 113,14 & 4,00 & 0,83 & 1,6 \\
\hline 90 & 8,40 & 3,40 & 1,05 & 6,3 & 346 & 64,27 & - & - & 1,5 & 556 & 114,26 & - & & 1,6 \\
\hline 100 & & 20 & 1,00 & 6,2 & 350 & 65,36 & 3,67 & 0,71 & 1,4 & 560 & 114,78 & 3,80 & 0,91 & 2,0 \\
\hline 110 & 10,13 & 3,18 & 0,77 & 5,8 & 356 & $67,($ & - & - & 1, & 566 & & - & & 2,4 \\
\hline 112 & 10,38 & 3,49 & 0,91 & & 360 & & 3,70 & 0,92 & 0, & 570 & & 3,61 & 1,06 & 2,6 \\
\hline 120 & & - & - & 5,3 & 366 & & & - & 1 , & 576 & & - & - & 2,8 \\
\hline 122 & & 3,8 & 0,7 & - & 368 & & & & 1 , & 580 & & 3,59 & 0,98 & 3,4 \\
\hline 130 & 12,20 & 3,84 & 0,69 & 5,4 & 370 & 70,82 & 3,38 & 0,62 & 1,0 & 590 & 118,70 & 3,46 & 1,08 & 3,5 \\
\hline
\end{tabular}


TABLE 8b. (continued)

\begin{tabular}{|c|c|c|c|c|c|c|c|c|c|c|c|c|c|c|}
\hline Depth, & Age, & $\partial 180$, & $13 \mathrm{C}$ & 3 & eptn, & Age, & d180, & $d 13 C$ & SSSI & epri, & Age, & $\partial 180$ & ग13C & $\overline{S S S T}$ \\
\hline $\mathrm{cm}$ & ka & $\%$ & $\%$ & ${ }^{\circ} \mathrm{C}$ & $\mathrm{cm}$ & ka & $\% o$ & $\% o$ & ${ }^{\circ} \mathrm{C}$ & $\mathrm{cm}$ & ka & $\% o$ & $\% o$ & ${ }^{\circ} \mathrm{C}$ \\
\hline 140 & 13,13 & 3,04 & 0,43 & 4,6 & 376 & 72,46 & - & - & 1,3 & 600 & 120,00 & 2,98 & 0,91 & 4,5 \\
\hline 142 & 13,32 & 3,53 & 0,46 & - & 378 & 73,00 & - & - & 1,8 & 605 & 120,83 & $\begin{array}{l}- \\
-\end{array}$ & - & 5,2 \\
\hline 147 & 13,85 & - & - & 4,0 & 380 & 73,54 & 3,47 & 0,68 & 2,5 & 610 & 121,67 & 2,77 & 0,87 & 5,2 \\
\hline 150 & 14,19 & 4,08 & 0,56 & 2,5 & 386 & 75,15 & - & - & 3,9 & 615 & 122,50 & - & - & 5,0 \\
\hline 155 & 14,77 & - & - & 1,2 & 388 & 75,69 & - & - & 4,1 & 620 & 123,33 & 2,48 & 0,71 & 5,3 \\
\hline 160 & 16,50 & 4,78 & 0,77 & 0,2 & 390 & 76,23 & 3,04 & 0,44 & 4,1 & 625 & 124,17 & - & - & 5,1 \\
\hline 162 & 17,50 & 4,45 & 0,43 & - & 396 & 77,85 & - & - & 3,9 & 630 & 125,00 & 2,61 & 0,53 & 5,2 \\
\hline 166 & 19,40 & - & - & $-0,1$ & 398 & 78,39 & - & - & 4,0 & 635 & 125,68 & - & - & 5,5 \\
\hline 169 & 20,60 & - & - & 0,2 & 400 & 78,92 & 3,53 & 0,58 & 4,0 & 640 & 126,36 & 2,74 & 0,46 & 5,3 \\
\hline 170 & 21,00 & - & - & 0,6 & 405 & 80,16 & - & - & 4,5 & 645 & 127,05 & - & - & 5,7 \\
\hline 172 & 21,80 & 4,10 & 0,35 & - & 409 & 80,78 & - & - & 3,8 & 650 & 127,73 & 2,81 & 0,49 & 6,1 \\
\hline 180 & 25,00 & - & - & 0,9 & 410 & 80,94 & 2,86 & 0,58 & 3,3 & 655 & 129,00 & - & - & 6,1 \\
\hline 182 & 25,31 & 4,25 & 0,54 & - & 420 & 82,50 & 3,14 & 0,66 & 3,0 & 660 & 130,67 & 3,46 & 0,46 & 5,6 \\
\hline 190 & 26,54 & & & 1,2 & 426 & 83,44 & - & - & 3,5 & 665 & 132,33 & - & - & 4,8 \\
\hline 192 & 26,85 & 4,29 & 0,07 & $\begin{array}{ll}- & -1 \\
-1\end{array}$ & 430 & 84,06 & 3,44 & 0,77 & 3,7 & 670 & 134,00 & 4,21 & 0,64 & 2,9 \\
\hline 200 & 28,08 & 4,11 & 0,53 & 1,1 & 437 & 85,26 & - & - & 3,6 & 680 & 137,33 & 3,97 & 0,41 & 1,4 \\
\hline 202 & 28,39 & 4,17 & 0,49 & - & 440 & 86,04 & 3,54 & 0,75 & 2,9 & 690 & 140,67 & 4,18 & 0,02 & 0,2 \\
\hline 210 & 29,62 & 4,06 & 0,65 & 0,7 & 446 & 87,59 & - & - & 1,8 & 700 & 144,00 & 3,64 & 0,19 & $-0,3$ \\
\hline 220 & 31,20 & 4,05 & 0,65 & 0,7 & 450 & 88,63 & 3,65 & 0,72 & 1,1 & 710 & 147,33 & 3,57 & $-0,15$ & 0,0 \\
\hline 230 & 33,20 & 3,82 & 0,75 & 0,7 & 456 & 90,19 & - & - & 0,8 & 712 & 148,00 & 4,46 & 0,02 & - \\
\hline 240 & 35,20 & 3,68 & 0,75 & 0,9 & 460 & 91,22 & 3,60 & 0,83 & 1,3 & 720 & 150,67 & 4,04 & $-0,03$ & 0,5 \\
\hline 250 & 37,57 & 4,00 & 0,67 & 0,9 & 466 & 92,78 & & - & 1,7 & 730 & 154,00 & 3,95 & $-0,02$ & 0,8 \\
\hline 260 & 40,17 & 3,51 & 0,48 & 0,7 & 470 & 93,82 & 3,38 & 0,93 & 1,9 & 740 & 157,33 & 3,93 & 0,08 & 0,6 \\
\hline 270 & 42,38 & 3,78 & 0,71 & 0,4 & 476 & 95,37 & - & - & 1,9 & 750 & 160,67 & - & - & 0,6 \\
\hline 280 & 43,63 & 3,83 & 0,45 & 0,5 & 480 & 96,41 & 3,34 & 0,82 & 2,1 & 752 & 161,33 & 3,64 & 0,35 & - \\
\hline 286 & 44,38 & - & - & 0,7 & 486 & 97,96 & - & - & 2,0 & 760 & 164,00 & - & - & 0,2 \\
\hline 290 & 44,88 & 3,86 & 0,49 & 1,3 & 489 & 98,74 & - & - & 2,1 & 762 & 164,67 & 3,46 & 0,30 & \\
\hline 296 & 45,63 & - & - & 1,6 & 490 & 99,00 & - & - & 2,1 & & & & & \\
\hline
\end{tabular}

The SST values are smoothed with a five-point Gaussian filter.

explained by a shift between the polar and subpolar floral assemblages. Indeed, a significant fraction of species associated with sea ice (epontic species - see factor 2 comments) appears during the cold events of isotopic stages 5, 3, and 2 (Figure 12). Change in the flora during interglacial time (particularly during isotopic stages 5.5, 5.1, and Holocene) is marked by an increase in the relative percentages of subantarctic species (as $T$. nitzschioides / 1 ).

The estimated summer SST is not significantly different from results obtained with the earlier transfer function (DTF 28/33/3) which was defined for the southern ocean by Pichon et al. [1987]. However, communality was systematically lower $\approx$ 0.75 ) during glacials in the previous study. The effects of silica dissolution before burial, which are taken into account by the new DTF 166/34/4, imposed therefore only minor limitations on the reliability of the main modern biogeographic assemblages. Analogues of the increased preponderance during glacials of dissolution- resistant species (as $T$. lentiginosa $/ 6$ and winter stages of $E$. antarctica $/ 18$ ) can only be found within samples artificially dissolved in the laboratory, independently of their geographic origin.

We have seen that the modern hydrological conditions at the site of core MD 84-527 correspond to a strong temperature inversion between 30 and 70 $m$ depth. The SST estimated by the DTF for the core top, around $+7^{\circ} \mathrm{C}$, is compatible with a mean depth of development of $20 \mathrm{~m}$, and more probably with growth within the upper $30 \mathrm{~m}$.

For core MD 84-551, the core top SST derived from the diatom flora appears too warm by about $2.5^{\circ} \mathrm{C}\left(+4.5^{\circ} \mathrm{C}\right.$, compared with $+2^{\circ} \mathrm{C}$ in the atlases of Gordon and Molinelli [1982] and Levitus [1982]]. This error is attributed to the presence, in low amounts $(\approx 0.3 \%)$, of the Subantarctic diatom $T$. nitzschioides $/ 1$. Tests done without taking into account that species lower the temperature estimate to $+2.5^{\circ} \mathrm{C}$. A small contribution, by coring disturbance of the core top, from the subsurface high abundance 

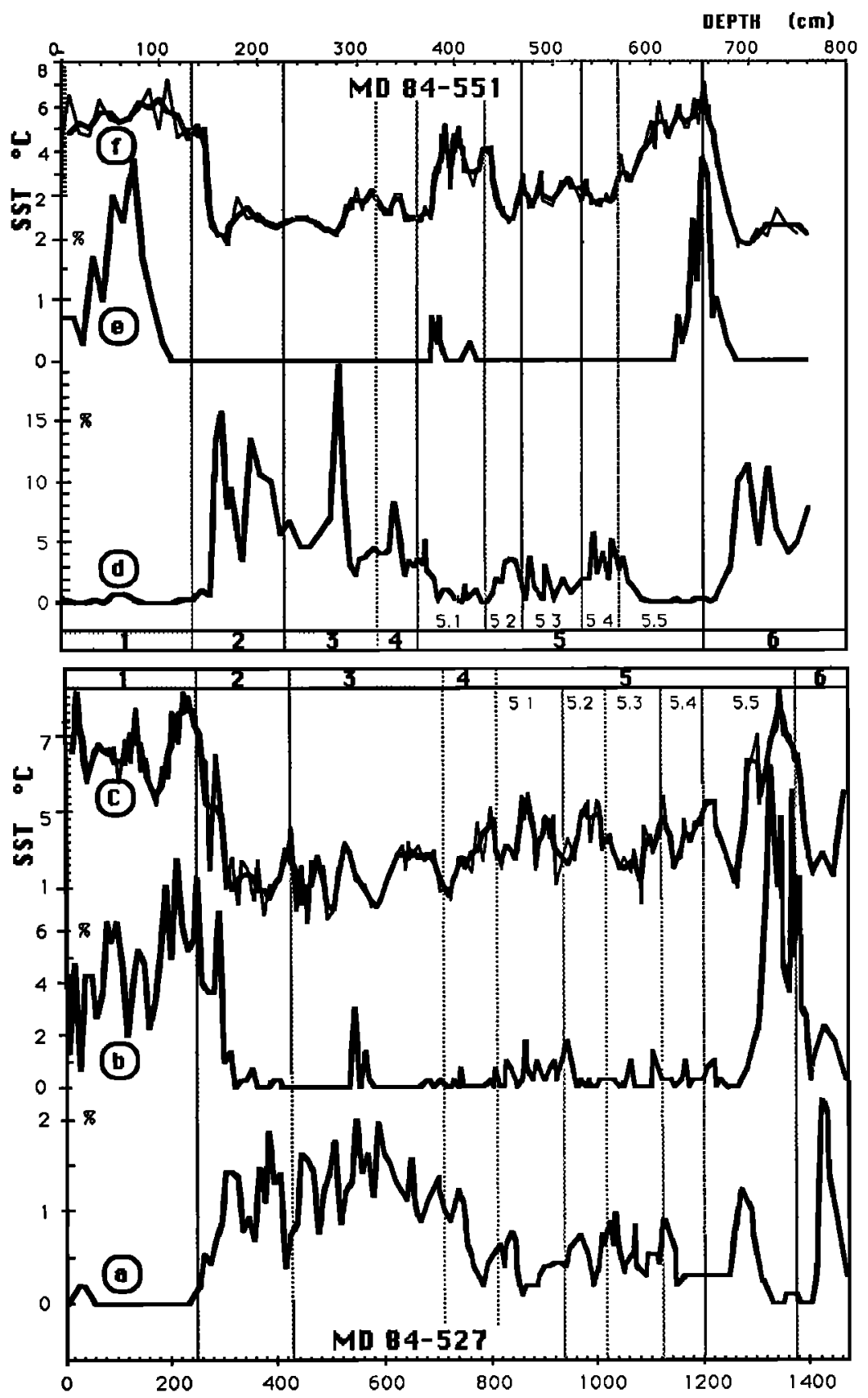

Fig. 12. Distribution with depth and Emiliani's stages in cores MD 84-527 (44. S, 51 ${ }^{\circ} \mathrm{E} ; 3,262 \mathrm{~m}$ depth) and MD 84-551 $\left(55^{\circ} \mathrm{S}, 73^{\circ} \mathrm{E} ; 1,504 \mathrm{~m}\right.$ depth) of (a) sum of relative abundance of 4 species associated with sea ice (Nitzschia curta 131, Actinocyclus actinochilus $/ 28$, Nitzchia sublineata 134, Nitzschia cylindrus /22) in core MD 84-527; (b) relative abundance (in percent) of Subantarctic species T. nitzchioides/1 in core MD 84-527; (c) diatom summer SST in core MD 84-527; (d) sum of relative abundance (in percent) of four species associated with sea ice (Nitzschia curta /31, Actinocyclus actinochilus /28, Nitzchia sublineata /34, Nitzschia cylindrus /22) in core MD 84-551; (e) relative abundance (in percent) of Subantarctic species T. nitzchioides/1 for core MD 84551; (f) diatom summer SST in core MD 84-551. 
TABLE 9. Age-Depth Relationships

\begin{tabular}{|c|c|c|c|c|c|c|}
\hline \multicolumn{2}{|c|}{ MD 84-527 Sediment Core } & \multicolumn{2}{|c|}{ MD 84-551 Sediment Core } & \multicolumn{3}{|c|}{ Vostok Ice Core } \\
\hline Depth, cm & Age, ka & Depth, cm & Age, ka & Depth, m & "Ice" Age, ka & "Ocean" Age, ka \\
\hline 0 & $1^{*}$ & 0 & 0,8 & 28 & 00 & 01 \\
\hline 60 & 4* & 109 & 10 & 244 & 09 & 10 \\
\hline 100 & $6 *$ & 117 & $11 *$ & 295 & 11 & 12 \\
\hline 180 & $8^{*}$ & 144 & $13.5^{*}$ & 370 & 16 & 15 \\
\hline 225 & $9.5^{*}$ & 157 & 15 & 553 & 31 & 24 \\
\hline 280 & $11.5^{*}$ & 165 & 19 & 696 & 42 & 42 \\
\hline 300 & $15^{*}$ & 180 & 25 & 759 & 47 & 50 \\
\hline 324 & $25^{*}$ & 219 & 31 & 844 & 53 & 59 \\
\hline 358 & $28 *$ & 244 & 36 & 1117 & 76 & 73 \\
\hline 440 & $31 *$ & 267 & 42 & 1202 & 82 & 85 \\
\hline 562 & 43 & 307 & 47 & 1281 & 88 & 93 \\
\hline 670 & 54 & 330 & 55 & 1369 & 95 & 101 \\
\hline 765 & 60 & 345 & 64 & 1502 & 107 & 110 \\
\hline 810 & 68,8 & 378 & 73 & 1599 & 116 & 116 \\
\hline 880 & 72,5 & 404 & 80 & 1687 & 123 & 123 \\
\hline 930 & 83,5 & 436 & 85 & 1857 & 135 & 129 \\
\hline 950 & 86,2 & 517 & 106 & 1940 & 143 & 138 \\
\hline 1000 & 92,7 & 554 & 114 & & & \\
\hline 1044 & 95,5 & 600 & 120 & & & \\
\hline 1081 & 104 & 630 & 125 & & & \\
\hline 1120 & 107 & 652 & 128 & & & \\
\hline 1180 & 111 & 670 & 134 & & & \\
\hline 1200 & 116 & 750 & 155 & & & \\
\hline 1222 & 118,8 & & & & & \\
\hline 1307 & 119 & & & & & \\
\hline 1324 & 121 & & & & & \\
\hline 1354 & 126 & & & & & \\
\hline 1384 & 130 & & & & & \\
\hline 1390 & 134 & & & & & \\
\hline
\end{tabular}

The stared ages for core MD 84-527 are derived from AMS dated planktic Foraminifera [Labracherie et al., 1989].

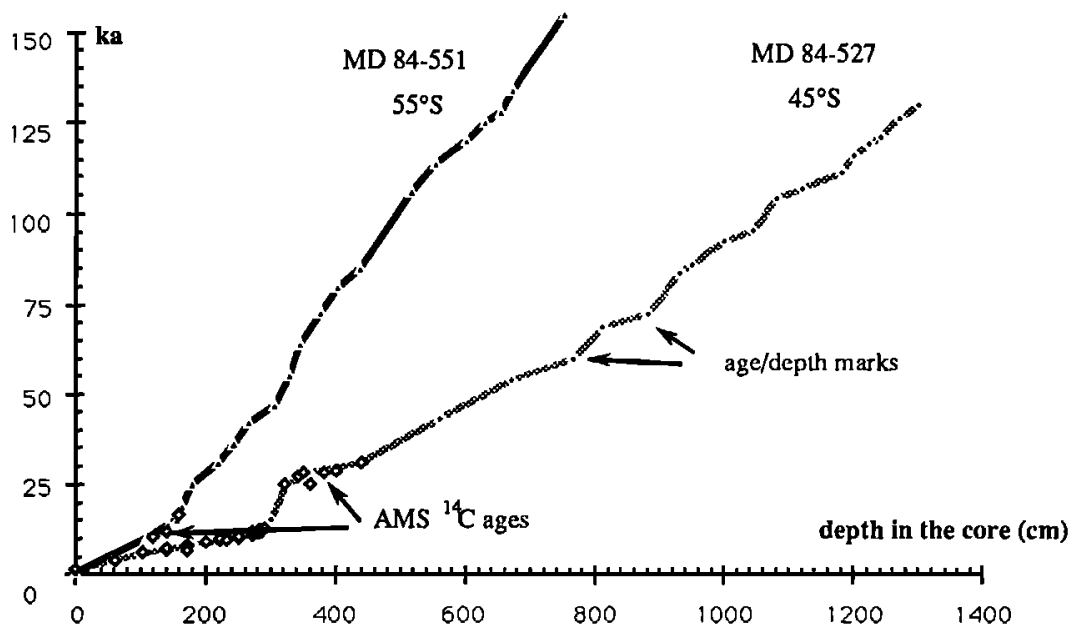

Fig. 13. Age versus depth relationships for cores MD 84-527 and MD 84-551. 


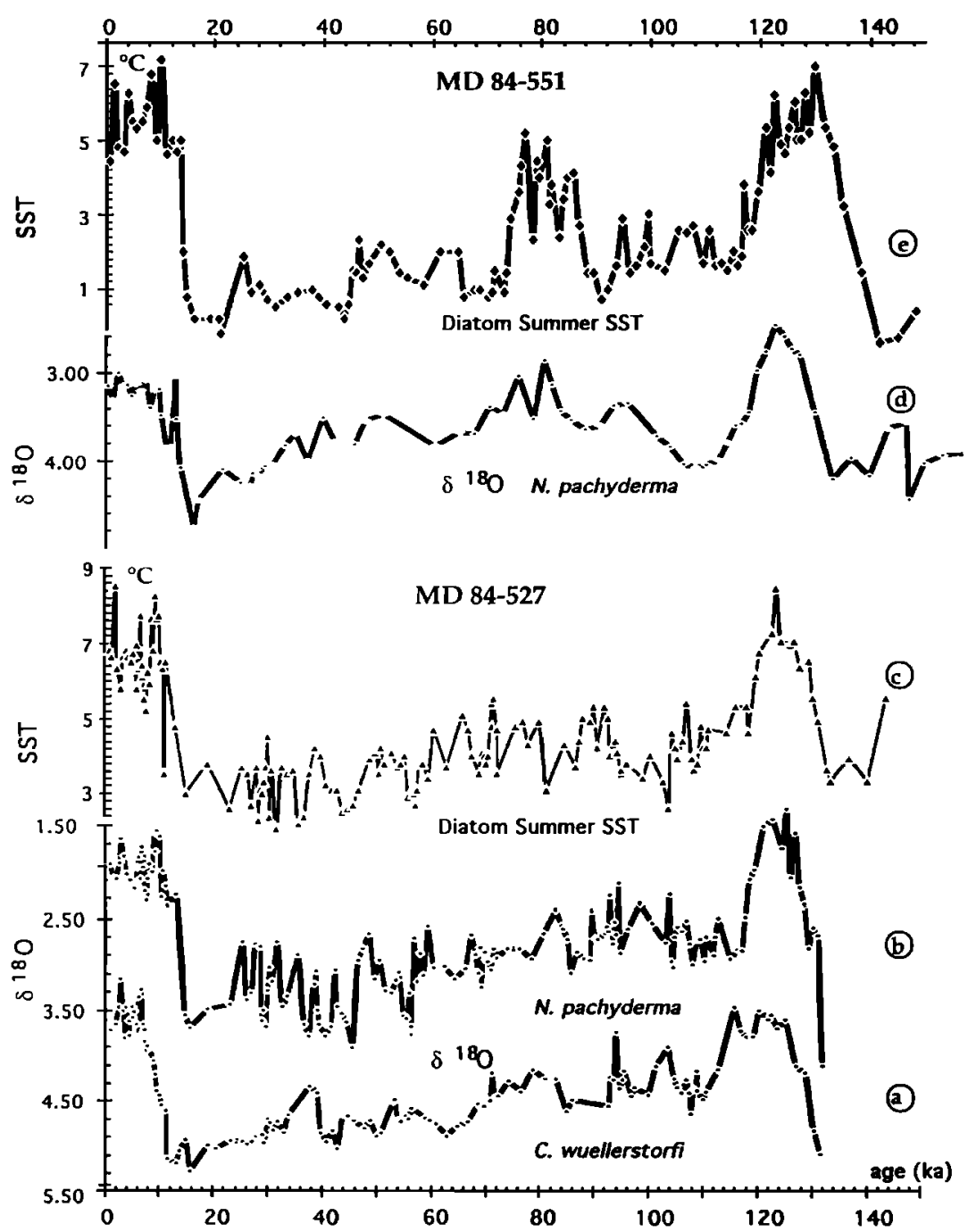

Fig. 14. Distribution versus calculated ages in the cores MD 84-527 (44. $\left.\mathrm{S}, 51^{\circ} \mathrm{E} ; 3,262 \mathrm{~m} \mathrm{depth}\right)$ and $\mathrm{MD} 84-$ $551\left(55^{\circ} \mathrm{S}, 73^{\circ} \mathrm{E} ; 1,504 \mathrm{~m}\right.$ depth) of (a) $\delta^{18} \mathrm{O}$ of the benthic foraminifera Cibicides wuellerstorfii in core MD 84-527; (b) $\delta^{18} \mathrm{O}$ of $N$. pachyderma s. in core MD 84-527; (c) diatom summer SST in core MD 84-527; (d) $\delta^{18} \mathrm{O}$ of $N$. pachyderma s. in core MD 84-551; (g) diatom summer SST in core MD 84-551.

peak of $T$. nitzschioides /1 (Figure 12e) would explain the difference.

For the LGM period, the SST estimates derived from the DTF and from the N. pachyderma s. $\delta^{18} \mathrm{O}$ are similar: $+3^{\circ} \mathrm{C}$ at the location of cores MD 73-025 and MD 84-527 for both $\delta^{18} \mathrm{O}$ and DTF, and $+0.2^{\circ} \mathrm{C}$ $\left(\delta^{18} \mathrm{O}\right) /+0.8^{\circ} \mathrm{C}(\mathrm{DTF})$ at $160 \mathrm{~cm}$ in core MD $84-551$ (Table $8 \mathrm{~b}$ ). This comparison, although limited, gives us some confidence in the quality of the estimates.

If we consider now the shape of the DTF SST records from both cores through the whole glacial/interglacial period (Figure 11 and 12), significant differences appear even if changes in sedimentation rates are taken in consideration. The record from Subantarctic core MD 84-527 is similar to the published SST record of subtropical core RC 11-120 [Hays et al., 1976b], with an early cooling at the end of substage 5.5, and apparently real pseudoperiodic oscillations of high frequency over a generally cold period that covers the whole of isotopic stages 5.4 to 2 . The higher latitude core $\mathrm{MD}$ 84-551 shows a relatively warm event during isotope substage 5.1. In both cores, the cool episodes are in phase with the high $N$. pachyderma $s . \delta^{18} \mathrm{O}$ events and the large relative amounts of sea ice diatoms (Figure 12). 


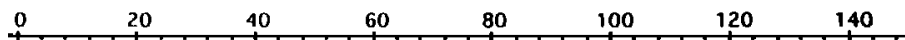

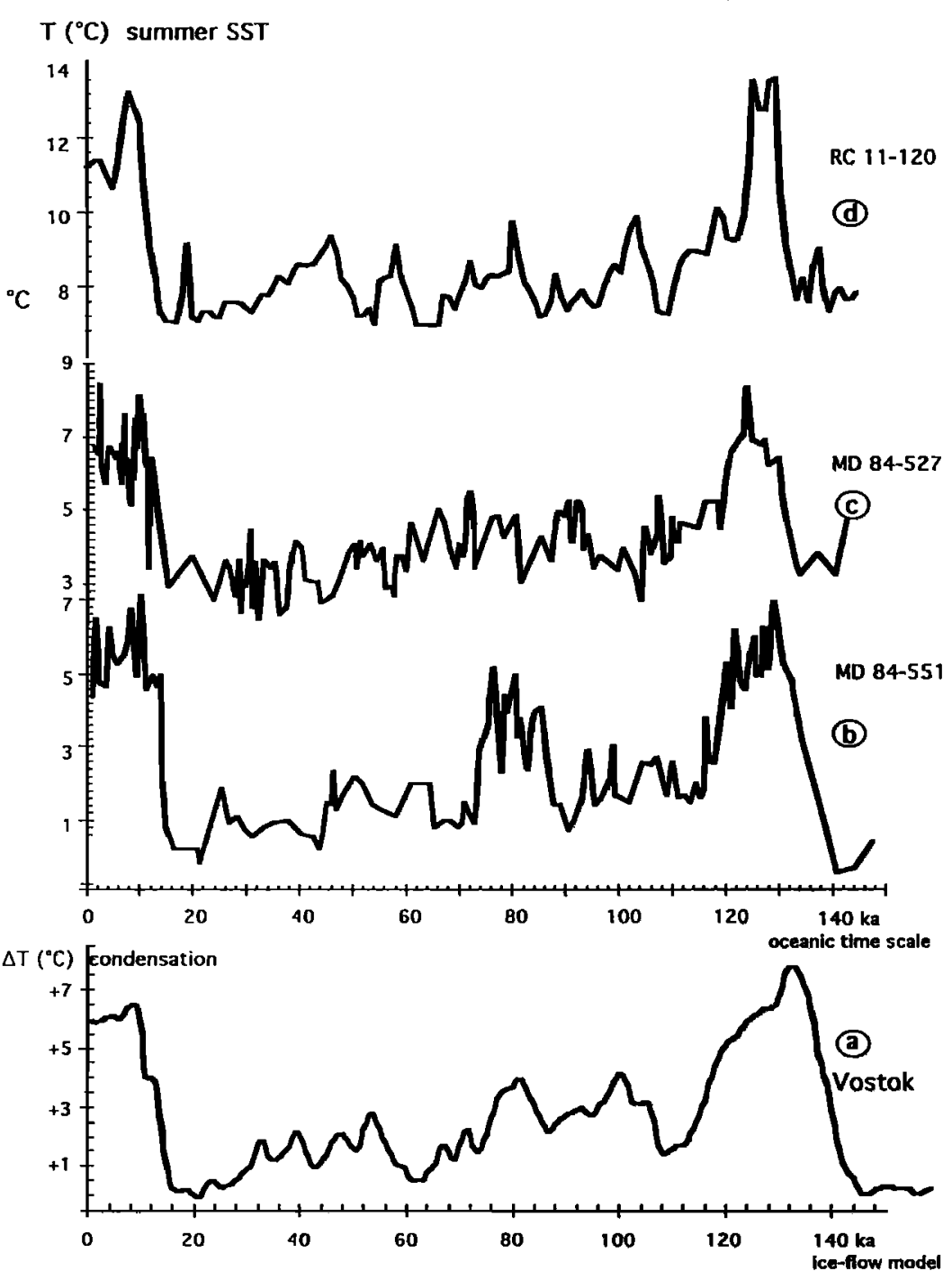

Fig. 15. Comparison between SST changes of southern ocean and air temperature over Antarctica: (a) Variation with depth of Vostok temperature derived from stable-isotope measurements [from Jouzel et al., 1987], reported in the time scale derived from ice flow model. (b) Variation of estimated summer SST in core MD 84551; (c) variation of estimated summer SST in core MD 84-527; (d) variation of estimated summer SST in core RC 11-120 [from Martinson et al., 1987]. Cores MD 84-527 and MD 84-551 are reported in the "oceanic" time scale constructed in the present work.

\section{Chronostratigraphic Scale}

To allow for a more detailed discussion of the signals and their comparison with other records, a chronostratigraphic scale was constructed. Carbon 14 dating of $N$. pachyderma s. and Globigerina bulloides, obtained by accelerator mass spectrometry, is available for the top $4.4 \mathrm{~m}$ of core MD 84-527, and three levels within the upper part of core MD 84-551 [Labracherie et al., 1989]. The ${ }^{14} \mathrm{C}$ ages are corrected by -480 years to take into account the present apparent surface water age at $45^{\circ} S$ [Bard et al 1989]. The benthic $\delta^{18} \mathrm{O}$ analyses of core MD 84-527 has been used to define the chronological markers below $4 \mathrm{~m}$, by detailed comparison with the benthic foraminifera $\delta^{18} \mathrm{O}$ record of the Pacific Ocean core V 19-30 [Shackleton and Pisias, 1985]. This core is itself well constrained within the SPECMAP time scale [Martinson et al., 1987].

Large changes in sedimentation rates result from fluctuations of the diatom opal fluxes, with a decrease to $<2 \mathrm{~cm} / \mathrm{kyr}$ during the Last Glacial 


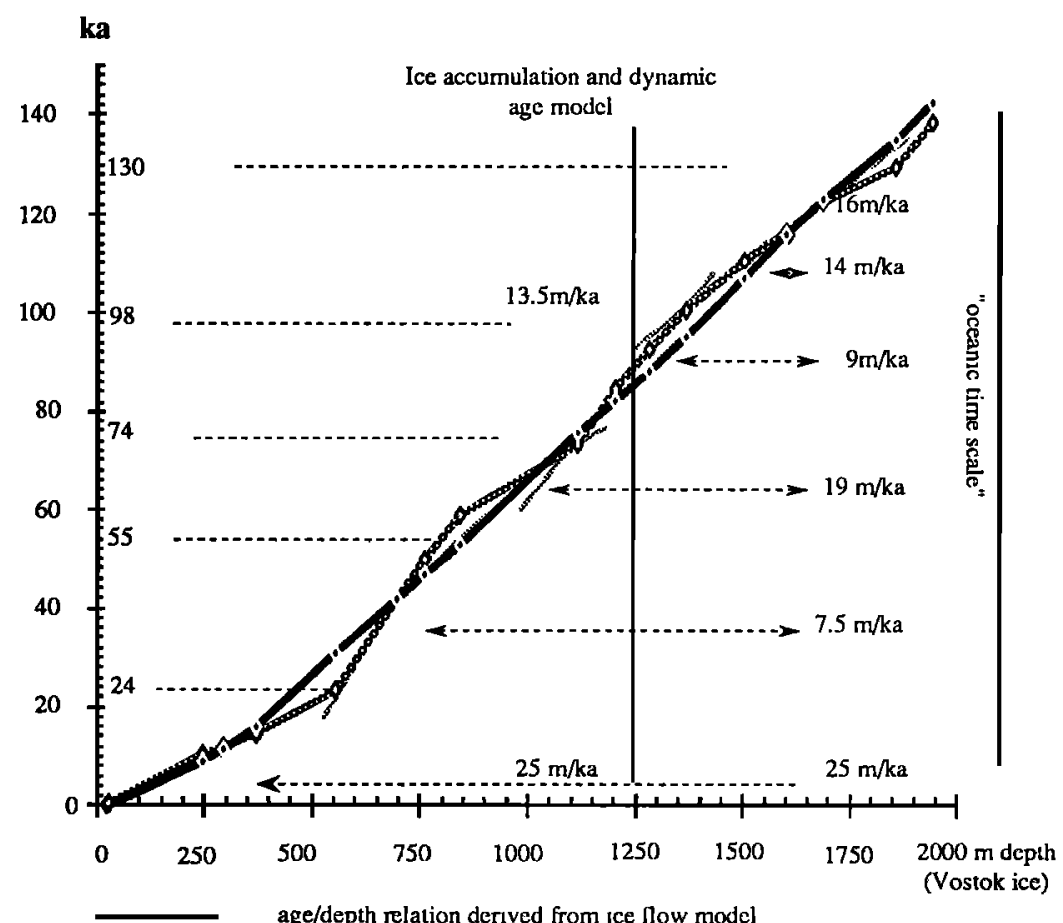

$\hookleftarrow \quad$ age/depth relation derived from correlation with the oceanic record

Fig. 16. Age-depth relations built using correlative structure between temperature profiles from the MD 84-551 (with the "oceanic" time scale developed in the present paper) and the Vostok ice core.

Maximum, and increases to $>30 \mathrm{~cm} / \mathrm{Kkyr}$ during interglacials. But a comparison of the benthic $\delta^{18} \mathrm{O}$ and $\delta^{13} \mathrm{C}$ signals in core MD $84-527$ with available high resolution benthic records does not show any evidence of a hiatus. In contrast, in the lower part of the record (between 1222 and $1306 \mathrm{~cm}$ ), the middle of stage 5.5 is apparently over-expended by a layer of pure diatom ooze, $84 \mathrm{~cm}$ thick. This layer was substracted prior to the age calibration.

The comparison between cores MD 84-527 and MD 84-551 was done with available isotopic $\left(\delta^{18} \mathrm{O}\right.$ and $\delta^{13} \mathrm{C}$ ) and SST data, for maximum coherency beween the reconstructed records. The general correspondance is given by the $N$. pachyderma $\delta^{13} \mathrm{C}$ signal [Labeyrie and Duplessy, 1985]. The proposed chronostratigraphical pointers are reported in Table 9 and Figure 13. They take into account the systematic lead of the planktic foraminifera $\delta^{18} \mathrm{O}$ versus the benthic records in core MD 84-527 (by 4 to $5 \mathrm{ka}$ ) at each of the transitions between stages $6 / 5.5,5.5 / 5.4$, and $2 / 1$. Correlations within substages of stage 3 and 5 , especially for core MD 84-551, are tentative. There is no published reference for the internal structure of these periods at high southern latitudes that could help us to specify the time scale. The sedimentation rate is assumed to be constant where constraints are absent. The SST and $\delta^{18} \mathrm{O}$ records are reported versus. age for both cores in Table 8a and 8b, and Figure 14.

\section{Comparison Between the Ocean SST Records and the Vostok Air-Temperature Record}

The Vostok record. The Vostok air-temperature record [Lorius et al., 1985; Jouzel et al., 1987; Lorius et al., 1990] is the only published continuous temperature record available for more than one climatic cycle in high southern latitudes. Strong climatic connections should exist between the Antarctic and the surrounding waters, as both latent and sensible heat transports to the ice sheet are directly dependent upon the distribution of surface water temperature over the southern ocean. We present in increasing latitudinal order, the estimated temperature changes of cores RC 11-120 (a Subtropical temperature record published by Hays et al. [1976a] and Martinson et al. [1987]], MD 84527, MD 84-551, and Vostok (Figure 15). We used for the Vostok ice record the changes in air temperature estimated just above the inversion layer 

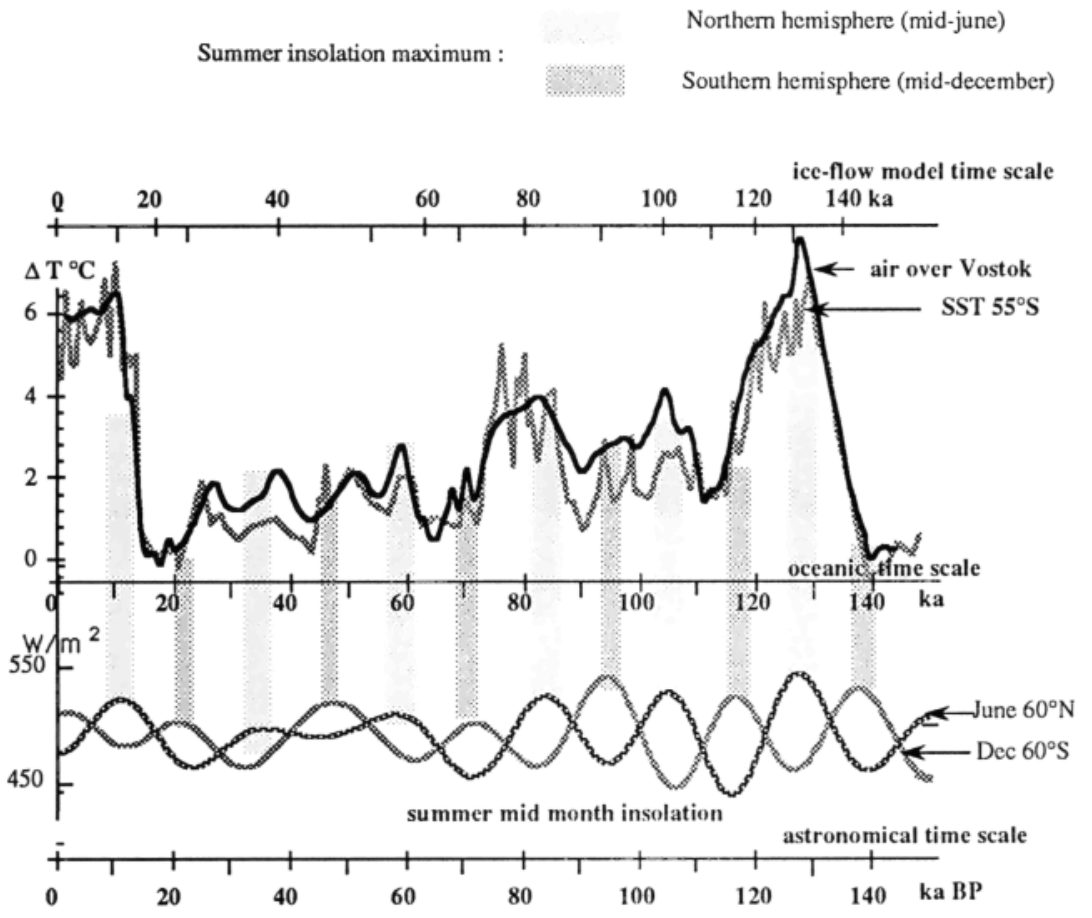

Fig. 17. Comparison between summer SST estimates of core MD 84-551 (55 $\mathrm{S})$ and Vostok changes in Vostok air temperature (at the inversion layer). Both the "oceanic" time scale (linear) and the ice flow model time scale (no linear) areb reported in abscissa. The summer insolation (mid-June for $60^{\circ} \mathrm{N}$ and mid-December for $60^{\circ} \mathrm{S}$ ) is reported in the astronomical time scale, following Berger [1978] and Berger and Loutre [1991].

and the time-scale derived from an ice flow model [Lorius et al., 1990].

Broad similarities can be seen among the four records. The MD 84-551 and Vostok temperature records are remarkably similar. They may be correlated in detail, to allow direct comparison of the records in the same time scale. The resulting agedepth relationship is given in Table 9 and Figure 16. We have reported also the age-depth relation derived from the ice flow model [Lorius et al., 1985]. Differences of 3-6 Ky between the time-scales derived from the ice-flow model and the ocean records appear around $30,50,95$, and $135 \mathrm{ka}$. This is because the oceanic time-scale predicts relatively large changes in ice accumulation rate (by a factor 3 ) between warm and cold episodes.

With the proposed time scales, the signals of core MD 84-551 and Vostok are well correlated $\left(\mathrm{r}^{2}=\right.$ 0.86 ), with a regression line of slope 1 over the whole record (Figure 17). Minor adjustments over the complete records, using the Martinson [1982] mapping method, increase $\mathrm{r}^{2}$ to 0.96 with 15 coefficients in the mapping function. However, the time scale of core MD 84-551 is not precise enough to exploit these detailed adjustments.

Discussion The Vostok temperature signal which is derived from the ice flow model [Lorius et al., 1985] is not compatible with the oceanic time scale, in particular for the last interglacial [Martinson, 1987]. Jouzel et al. [1987] have discussed this problem in detail. The question is especially important not only to resolve leads and lags between the atmosphere and ocean changes but also for understanding the links between northern and southern hemisphere climates. Part of the discrepancy may be attributed to real differences in the timing of the climatic changes. CLIMAP Project Members [1984] has described the early warming and cooling of the surface water around isotopic stage 5.5. The measurements done in core MD 84527 confirm that southern ocean led the surface water warming by about 3-5 k.y., and the initiation of the cooling by $\sim 5 \mathrm{k}$.y. (compared to the benthic foraminifera signal). Similar phase difference appeared at the isotopic transitions $5 / 4$ and $2 / 1$ (Figure 14).

However, the lead of the surface water temperature changes does not explain all the differences between the Vostok and the ocean chronostratigraphy. We also must introduce significant changes in ice accumulation rate over the Antarctic to fit both temperature records within the oceanic time-scale. The corrections proposed are larger than the uncertainties of the oceanic time scale only for the better constrained part of the MD 84-551 record (isotopic stage 5.5). They stay within those of the ice flow model [Lorius et al., 1985; Jouzel et al., 
1987]. The general validity of the ice flow model is thus supported by the data. Yet it is possible, if the proposed correlations are taken at face value, that the changes in ice accumulation rate between warm and cold intervals may have been larger than estimated. Adjustments of the Vostok record in the same direction were also suggested by Petit et al. [1990] to fit the glacial increase in dust content of the Vostok ice core with other dust records from different ocean cores and with the China loess record of Kukla [1987].

As already observed by Lorius et al. [1985] and discussed in detail by Lorius et al. [1990], the air temperature changes over Vostok appear well in phase with the summer insolation at high northern latitudes (Figure 17). Core MD 84-551, at $55^{\circ} \mathrm{S}$, shows similar characteristics for both summer SST and $N$. pachyderma $\delta^{18} \mathrm{O}$. We have run a Blackman-Tuckey cross spectral analysis of these parameters and the mid-summer insolation at $60^{\circ}$ North and South latitude [Berger and Loutre, 1991]. The maximum spectral power corresponds to 23 $\mathrm{kyr} / \mathrm{cycle}$, with a smaller component at $44 \mathrm{kyr} / \mathrm{cycle}$ for both parameters. The $\delta^{18} \mathrm{O}$ variability shows a higher coherence with the northern hemisphere than the southern hemishere summer insolation in both frequency bands $(0.95$ and 0.92 , compared with 0.86 and 0.72 , respectively for 23 and $44 \mathrm{kyr} /$ cycle). SST and insolation have a lower coherency, but with no special response to the southern insolation $(0.72$ for $23 \mathrm{kyr} / \mathrm{cycle}$ with the summer insolation at $60^{\circ} \mathrm{N}$, and 0.55 at $60^{\circ} \mathrm{S}$ ). This implies therefore that the long term climatic variability of the southern hemisphere is responding directly to the early evolution of the northern ice sheets, and its links with earth albedo, deep ocean circulation and green house gas content in the atmosphere, as found by CLIMAP Project Members [1984] for the last interglacial period, and reviewed by Lorius et al. [1990]. The southern insolation influence, although qualitatively apparent in Figure 17 is not demonstrated on simple statistical grounds.

These results do not preclude the possibility that SST are influenced locally by the changes in southern summer insolation, which may drive part of the sea ice distribution. This would explain the peculiar high frequency structure of the SST and planktonic foraminifera $\delta^{18} \mathrm{O}$ in our southern ocean cores, both northern and southern influences being opposed in phase for precession cycle (Figure 14).

The glacial-interglacial range of temperature, $6^{\circ} \mathrm{C}$, is analogous to what Broecker and Denton [1989] estimated for global high latitude changes. However, the apparent linear response of the changes in air temperature over the Vostok site to the southern ocean summer SST (with a slope $=1$ ) emphasizes the simple links that exist between Antarctic and southern ocean climatologies.

\section{CONCLUSIONS}

A diatom transfer function, which estimates sea surface temperatures with a precision of $\pm 1^{\circ} \mathrm{C}$ in the temperature range $-1^{\circ}$ to $+10^{\circ} \mathrm{C}$, has been developed for the southern ocean. The effect of dissolution before burial [Pichon et al., 1992] was minimized by adding to the reference assemblages a set of surface samples representative of the range of SST and partially dissolved under laboratory control. This allowed the definition of a variance factor independent of sea surface temperature that correlates well with the measured amount of silica dissolution. As the multiple regression varimax method isolates orthogonal factors, the newly constructed temperature DTF $166 / 34 / 4$ is, by definition, independent of dissolution. Application of this transfer function over the last climatic cycle in two sediment cores with post deposition silica loss $<20 \%$ give results not significantly different, apart from an increased communality, from a transfer function built without taking into account dissolution (DTF 28/33/3) [Pichon et al., 1987]. However, differences become significant for larger silica losses. DTF $166 / 34 / 4$ still appears to be valid with silica losses in the $50-70 \%$ range.

The time-scale of the reconstructed paleotemperature records was established by referring the benthic $\delta 180$ record of Subantarctic core MD 84-527 $\left(43^{\circ} \mathrm{S}\right)$ to the ocean isotopic time scale [Shackleton and Pisias, 1985; Martinson et al., 1987]. Detailed correlations between the paleoclimatological indicators of MD 84-527 and Antarctic core MD $84-551\left(55^{\circ} \mathrm{S}\right)$ provide the framework for a high-resolution deep-sea chronology. The resulting lead in planktonic foraminifera $\delta^{18} \mathrm{O}$ and SST, when compared with the "global" benthic $\delta^{18} \mathrm{O}$ signal, is of the order of 4 k.y. for the warming during the $6 / 5.5$ and $2 / 1$ transitions, and 5 to 6 k.y. for the cooling at the 5.5/5.4 transition. This early cooling is in fact one of the major characteristics of the southern ocean climatic and isotopic records. The correlation between summer SST changes of the southern waters at $55^{\circ} \mathrm{S}$ and air temperature over Antarctica at Vostok offers the opportunity of a test of the validity of the ice accumulation and flow models. It suggests the possibility that major changes in ice accumulation rates occured between cold and warm episodes. This study opens the possibility of detailed comparisons between the ocean records and the Vostok ice core in terms of global climatology.

Acknowledgments. We gratefully acknowledge the generous contribution of samples from the Lamont-Doherty Geological Observatory core collections, R. Gersonde (Alfred Wegener Institut) and D.S. Cassidy of the FSU Antarctic Research Facility. M. Fontugne and J. L. Turon had a major 
role in the different APSARA coring cruises, we thank them as well as the captains and crews of the ship Marion Dufresne. Special thanks are extended to L. Burckle for his continuous support during the development of the transfer function and his review of this work. The manuscipt was considerably improved after detailed editing by $T$. Petersen.and $S$. Calvert. We benefited also from additional reviews by J.C. Duplessy, E. Boyle, K. G. Miller, and an anonymous reviewer. This work was supported by Centre National de la Recherche Scientifique, Institut National des Sciences de l'Univers, Programme National de la Dynamique du Climat, Commissariat à l'Energie Atomique, Mission Scientifique des Terres Australes et Antarctiques Françaises. CFR contribution $n^{\circ} 1299$.

\section{REFERENCES}

Baker, A. de C., The Circumpolar continuity of Antarctic plankton species, Discovery Rep. 24, 203-217, 1948.

Bard, E., L.D. Labeyrie, M. Arnold, M. Labracherie, J.J. Pichon, J. Duprat, and J.C. Duplessy, AMS- ${ }^{14} \mathrm{C}$ ages measured in deep sea cores from the Southern Ocean: implications for sedimentation rates during isotope Stage 2, Quat. Res., 31, 309-317, 1989.

Barnola, J.M., D. Raynaud, Y.S., Korotkevitch, and C. Lorius, Vostok ice core provides 160,000 year record of atmospheric $\mathrm{CO}_{2}$, Nature, 329, 408-414, 1987.

Bareille, G., Flux sédimentaires : Paleoproductivité et paleocirculation de l'océan Austral au cours des derniers 150000 ans. Thèse de l'Université de Bordeaux 1, Talence, 259 pp., 1991.

Bareille, G., M. Labracherie, L.D. Labeyrie, Pichon, J.J., and J.L. Turon, Biogenic silica accumulation rate during the Holocene in the Southern Indian Ocean, Mar. Chem., 35, 537551, 1991.

Berger, A., Long-term variations of caloric insolation resulting from the Earth's orbital elements, Quat. Res., 9, 139-167, 1978.

Berger, A., and M.F. Loutre, Insolation values for the climate of the last 10 million of years, Quat. Sci. Rev., 10, 297-317, 1991.

Boden, B.P., The diatom collected by the U.S.S. Cacopan in the Antarctic in 1947, J. Mar. Res., 8, 6-13, 1949.

Broecker, W.S., and G.H. Denton, The role of ocean-atmosphere reorganizations in glacial cycles, Geochim. Cosmochim. Acta, 53, 24652501, 1989.

Burckle, L.H., Diatom distribution and Paleoceanographic reconstruction in the southern ocean - Present and last glacial maximum, Mar. Micropaleontology, 9, 241-261, 1984.

CLIMAP Project Members, Seasonal reconstructions of the Earth's surface at the last glacial maximum, Geol. Soc. Am. Map Chart Ser., MC-36, 1981.

CLIMAP Project Members, The last interglacial ocean, Quat.Res., 21, 123-224, 1984.

Donahue, J.G., Diatoms as quaternary biostratigraphic and paleoclimatic indicators in high latitudes of the Pacific Ocean, Ph.D. thesis, Faculty of Pure Sci., Columbia Univ., Palisades, N. Y., 1970.

Duplessy, J.C., J. Moyes, and C. Pujol, Deep water formation in the North Atlantic Ocean during the last ice age, Nature, 286, 479-482, 1980.

Duplessy, J.C., L.D. Labeyrie, A. Juillet-Leclerc, F. Maitre, J. Duprat, and M. Sarnthein, Surface salinity reconstruction of the north Atlantic ocean during the last glacial maximum, Oceanol. Acta, 14, 311-324, 1991.

El-Sayed, S.Z., Observations on phytoplankton bloom in the Weddell Sea, in Biology of the Antarctic Seas IV, Antarc. Res. Ser., vol. 17, edited by G. A. Llano and I. E. Wollen, D. C., Washington, 1971.

Fenner, J., H.J. Schrader, and H. Wienigk, Diatom phytoplankton studies in the Southern Ocean, composition and correlation to the Antarctic Convergence and its paleoecological signifiance, in Initial Reports of the Deep Sea Drilling Project, Leg 35, pp. 757-814, U. S. Government Printing Office, Washington, D. C., 1976.

Fryxell, G.A., and G.A. Kendrick, Austral spring microalgae across the Weddell Sea ice edge: Spatial relationships found along a northward transect during AMERIEZ 83, Deep Sea Res., 1 , $1-20,1988$.

Fukase, S., Oceanographic condition of surface water between the south end of Africa and Antarctica, Nankyoku Shiryo, 15, 53-110, 1962.

Gordon, A.L., and E.J. Molinelli, Southern Ocean Atlas: Thermohaline and Chemical Distributions, Columbia University Press, New York, 1982.

Hargraves, P.E., Species composition and distribution of net plankton diatoms in the Pacific sector of the Antarctic Ocean, Ph.D. dissertation, 170 pp., Coll. of William and Mary, Williamsburg, V., 1968.

Hart, T.J. Phytoplankton periodicity in Antarctic surface waters, Discovery Rep., 21, 261-356, 1942.

Hasle, G.R., An analysis of the phytoplankton of the Pacific Southern Ocean, Hvalradets Skr., 52, 1-168, 1969.

Hays, J.D., A review of the Late Quaternary climatic history of Antarctic Seas, in Antarctic Glacial History and World Paleoenvironments, Proceedings of the Xth INQUA Congress, edited by E. M. van Zinderen Bakker, pp. 57-71, A. A. Balkelma, Rotterdam, Netherlands, 1978.

Hays, J.D., J. Imbrie, and N.J. Shackleton, Variations in the Earth's orbit: pacemakers of the ice ages, Science, 194, 1121-1132, 1976a. 
Hays, J.D., J.A. Lozano, N.J. Shackleton, and G. Irving, Reconstruction of the Atlantic Indian Ocean sectors of the 18,000 B.P. Antarctic Ocean, in Investigations of late Quaternary Paleoceanography and Paleoclimatology: Geol. Soc. America Mem. 145, edited by R. M. Cline and J. D. Hays, pp. 337-372, 1976 b.

Hendey N.I., The planktonic diatoms of the southern seas, Discovery Rep., 16, 151-364, 1937.

Imbrie, J., and N.G. Kipp, A new micropaleontological method for quantitative paleoclimatology: Application to a late Pleistocene Caribbean core, in The Late Cenozoic Glacial Ages, edited by K K. Turekian, pp. 71-181, Yale University Press, New Haven, Conn., 1971.

Imbrie, J., J.D. Hays, D.G. Martinson, A. McIntyre, A.C. Mix, J.J. Morley, N.G. Pisias, W.L. Prell, and N.J. Shackleton, The orbital theory of Pleistocene climate: support from a revised chronology of the marine $\delta^{18} \mathrm{O}$ record, in Milankovitch and Climate, Part 1, edited by A.L. Berger et al., pp. 269-305, D. Riedel, Hingham, Mass., 1984.

Jones, G.A., and D.A. Johnson, Displaced Antarctic diatoms in Vema Channel sediments: Late pleistocene/Holocene fluctuations in $\mathrm{AABW}$ flow, Mar. Geol., 58, 165-186, 1984.

Jouzel, J., C. Lorius, J.R. Petit, C. Genthon, N.I. Barkov, V.M. Kotlyakov, and V.M. Petrov, Vostok ice core: A continuous isotope temperature record over the last climatic cycle (160,000 years), Nature, 329, 402-408, 1987.

Kent, D.V., Apparent correlation of paleomagnetic intensity and climatic records in deep-sea sediments, Nature, 299, 538-539, 1982.

Kozlova, O.G., Diatoms of the Indian and Pacific Sectors of the Antarctic, translated in 1966 from Russian by Israel Program for Scientific Translations, U.S. clearing house for Federal Scientific and Technical Information, TT 6651154, S. Monson, 191 pp., Jerusalem, 1964.

Krebs, W.N., Ecologie and preservation of neritic marine diatoms, Arthur Harbor, Antarctica, Ph.D. dissertation, Univ. of California, Davis, 216 pp., 1977.

Kukla, G., Loess stratigraphy in Central China and correlation with an extended oxygen isotope stage scale, Quat. Sci. Rev., 6, 191-219, 1987.

Labeyrie, L.D., and J.C. Duplessy, Changes in the oceanic ${ }^{13} \mathrm{C} /{ }^{12} \mathrm{C}$ ratio during the last 140,000 years: High-latitude surface records, Paleogeogr. Paleoclimatol. Paleoecol., 50, 217-240, 1985.

Labeyrie, L.D., J.J. Pichon, M. Labracherie, P. Ippolito, J. Duprat, and J.C. Duplessy, Melting history of Antarctica during the past 60,000 years, Nature, 322, 701-706, 1986.

Labeyrie, L.D., J.C. Duplessy, and P.L. Blanc, Variations in mode of formation and temperature of oceanic deep waters over the past 125,000 years, Nature, 327, 477-482, 1987.

Labracherie, M., L.D. Labeyrie, J. Duprat, E. Bard, M. Arnold, J.J. Pichon, and J.C. Duplessy, The last deglaciation in the southern ocean, Paleoceanography, 4(6), 629-638, 1989.

Leventer, A., and R.B. Dunbar, Diatom flux in McMurdo Sound, Antarctica, $M a r$. Micopaleontol., 12, 49-64, 1987.

Leventer, A., and J.J. Pichon, Mechanisms of sedimentation, Proceedings of the Third Polar Diatom Colloquium, edited by M. Poulin, Can Tech. Rep. Fish. Aquat. Sci., 1781, 20-24, 1991.

Levitus, S., Climatological Atlas of the World Ocean, 173 pp., National Oceanic and Atmospheric Administration, Rockville, Md., 1982.

Lorius, C., J. Jouzel, C. Ritz, L. Merlivat, N.I. Barkov, Y.S. Korotkevitch, and V.M. Kotlyakov, A 150,000-year climatic record from Antarctic ice, Nature, 316, 591-596, 1985.

Lorius, C., J. Jouzel, D. Raynaud, J. Hansen, and H. Le Treut, The ice-core record: Climate sensitivity and future greenhouse warming, Nature, 347, 139-145, 1990.

Martinson, D.G., An inverse approach to signal correlation with applications to deep-sea stratigraphy and chronostratigraphy, Ph.D. thesis, Columbia Univ., Palisades, N. Y., 1982.

Martinson, D. G., N.G. Pisias, J.D. Hays, J. Imbrie, T.C. Moore, and N.J. Shackleton, Age dating and the orbital theory of the ice ages: Development of a high-resolution 0-300,000 year chronostratigraphy, Quat. Res., 27, 1-30, 1987.

Mikkelsen, N., Experimental dissolution of Pliocene diatoms, Nova Hedwigia, 64, 893-502, 1980.

Morley, J.J., and W. Robinson, Paleotemperature and faunal variations in two deep sea records from the northern Cape Basin, Geol. Soc. Am. Abstr. Programs, 12, 487, 1980.

O'Neil, J.R., R.N. Clayton, and T.K. Mayeda, Oxygen isotope fractionation in divalent metal carbonates, J. Chem. Phys., 51, 5547-5558, 1969.

Ostlünd, H.G., C. Craig, W.S. Broecker, and D. Spencer (Eds.), GEOSECS Atlantic, Pacific, and Indian Ocean Expeditions. Shorebased Data and Graphics, GEOSECS Atlas Ser., vol. 7, 200 pp., U.S. Government Printing Office, Washington, D.C., 1987.

Petit, J.R., Mounier, J. Jouzel, Y.S. Korotkevich, V.I. Kotlyakey, and C. Lorius, Paleoclimatological and chronological implications of the Vostok core dust record, Nature, 343, 56-58, 1990.

Pichon, J.J., M. Labracherie, L.D. Labeyrie, and J. Duprat, Transfer functions between diatom assemblages and surface hydrology in the 
southern ocean, Paleogeogr. Paleoclimatol. Paleoecol., 61, 79-95, 1987.

Pichon, J.J., G. Bareille, M. Labracherie, L.D. Labeyrie, A. Baudrimont, and J.L. Turon, Quantification of the biogenic silica dissolution in southern ocean sediments, Quat. Res., in press, 1992.

Quilty, P.G., K.R. Kerry, and H.J. Marchant, A seasonally recurrent patch of Antarctic planktonic diatoms, Search , 16(1-2), 48, 1985.

Robinson, S.G., The late Pleistocene paleoclimatic record of north atlantic deep sea sediments revealed by mineral magnetic measurements, Phys. Earth Planet Inter., 42, 22-47, 1986.

Shackleton, N.J., Attainment of isotopic equilibrium between ocean water and the benthonic foraminifera genus Uvigerina: Isotopic changes in the ocean during the last glacial, in les méthodes quantitatives d'étude des variations du climat au cours du pléistocène, edited by J. Labeyrie, pp. 203-210, Colloque CNRS, Les Presses du Centre National de la Recherche Scientifique, Gif/Yvette, France, 1974.

Shackleton, N.J., and N.G. Pisias, Atmospheric carbon dioxide, orbital forcing, and climate, in The Carbon Cycle and Atmospheric $\mathrm{CO}_{2}:$ Natural Variations Archean to Present, Geophys. Monogr. Ser., vol. 32, edited by E. T. Sundquist and W. S. Broecker, pp. 303-317, AGU, Washington, D. C., 1985.

Shemesh, A., L.H. Burckle, and P.N. Froelich, Dissolution and preservation of Antarctic diatoms and the effect on sediment thanatocoenoses, Quat. Res., 31, 288-308, 1989.
Sowers, T., M. Bender, D. Raynaud, Y.S. Korotkevich, and J. Orchardo, The $\delta^{18} \mathrm{O}$ of atmospheric $\mathrm{O}^{2}$ from air inclusions in the Vostok ice core: Timing of $\mathrm{CO}_{2}$ and ice volume changes during the penultimate deglaciation, Paleoceanography, 6, 679-696, 1991.

Wefer, G., G. Fischer, D.K. Fütterer, and R. Gersonde, Seasonal particle flux in the Bransfield Strait, Antarctica, Deep Sea Res. 35(6A), 891898, 1988.

Wefer, G., G. Fischer, D.K. Fütterer, R. Gersonde, S. Honjo, and D. Ostermann, Particle sedimentation and productivity in Antarctic waters of the Atlantic sector, in Geological History of the Polar Oceans: Arctic Versus Antarctic, edited by U. Bleil and J. Thiede, pp. 363-379, Kluwer Academic, Boston, Mass., 1990.

G. Bareille, J. Duprat, M. Labracherie, and J.J. Pichon, Département de Géologie et Océanographie, CNRS URA 197, Université de Bordeaux I, Avenue des Facultés, 33405 Talence cedex, France.

J. Jouzel, Laboratoire de Modélisation du Climat et de l'Environnement, DSM CEA Saclay, 91191 Gif sur Yvette cedex, France

L. D. Labeyrie, Centre des Faibles Radioactivités, Laboratoire mixte CNRS-CEA, Avenue de la Terrasse, 91198 Gif-sur-Yvette, France.

(Received April 4, 1991; revised March 13,1992; accepted March 20, 1992.) 